\title{
Euskal gatazka armatuaren historia hezkuntzako edukietan: azterketa diskurtsibo bat ${ }^{1}$
}

\author{
The history of the Basque armed conflict in schoolbooks: \\ a discursive analysis \\ Samara Velte* \\ Gizarte eta Komunikazio Zientzien fakultatea
}

$\mathrm{UPV} / \mathrm{EHU}$

LABURPENA: Euskal gatazkaren azken aro armatuaren (1960-2018) memoria ikastetxeetan lantzeko egin diren lehenbiziko ahaleginetako bat da Eusko Jaurlaritzak 2018an sortutako Herenegun material didaktikoa. Testuinguru diskurtsibo liskartsu baten erdian, are errelebantzia handiagoa du eskolako gaitegiak gatazkaren historiari buruzko narratibak sortzerako orduan; are gehiago kontuan hartzen badugu material horien hartzaileak dagoeneko gatazka biolentoari buruzko oroitzapen zuzenik ez daukan belaunaldi batekoak direla. Ikerketa honetan, material didaktiko horrek Johan Galtungen baketze inklusiboaren printzipioak betetzen ote dituen aztertzen dugu. Finean, bake negatibo baten ideia elikatzen duela ondorioztatzen dugu, eta, horren ordez, ikuspegi despolarizatzaileagoa dakarten narratibak sustatzea proposatzen dugu.

GAKO-HITZAK: Bakea, material didaktikoa, euskal gatazka, diskurtsoaren analisia, Bigarren Hezkuntza.

ABSTRACT: The didactic material Herenegun, created by the Basque Regional Government in 2018, is the first attempt to teach about the latest armed phase of the Basque conflict (1960-2018). In the middle of a disputed discursive context, schoolbooks receive an even greater relevance when creating narratives about the history of the conflict; this is accentuated by the fact that the addressees of these materials are already part of a generation that has no direct memories on the violent conflict. In this study, we analyse whether this school material complies with the principles of inclusive peacemaking as formulated by Johan Galtung. We conclude that they rather represent an idea of negative peace, and we propose to build on narratives with a de-polarising view instead.

KEYWORDS: Peace, schoolbooks, Basque conflict, discourse analysis, secondary education.

1 Lan honek Eusko Jaurlaritzaren Hezkuntza, Hizkuntza Politika eta Kultura Sailaren ikerketa taldeetarako laguntza (IT-881-16) eta Eusko Jaurlaritzaren doktoreaurreko ikerketarako laguntza jaso ditu.

\footnotetext{
* Harremanetan jartzeko / Corresponding author: Samara Velte. Euskal Herriko Unibertsitatea (UPV-EHU). Ikus-Entzunezko Komunikazioko Saila. Gizarte eta Komunikazio Zientzien Fakultatea. Sarriena auzoa, z/g. 48940 Leioa, Bizkaia - samara. velte@ehu.eus - https://orcid.org/0000-0001-9152-4499

Nola aipatu / How to cite: Velte, Samara. (2019). «Euskal gatazka armatuaren historia hezkuntzako edukietan: azterketa diskurtsibo bat». Tantak, 31(2), 41-73. (https://doi.org/10.1387/tantak.20983).

Jasotze-data: 2019/07/04; Onartze-data: 2019/09/13.

ISSN 0214-9753 - elSSN 2444-3581 / ( C) 2019 UPV/EHU
}

(c) (i) Obra hau Creative Commons Atribución 4.0 Internacional-en 


\section{SARRERA}

2019ko uztailean, hamarkada bat beteko da ETAk bere azken atentatua egin zuenetik. Talde horren armagabetzea eta desegitea beranduago heldu diren arren, euskal gatazka armatuaren etapa esanguratsu bat duela 10 urte amaitu zela esan dezakegu, beraz. Datu honek, beharbada, ez dauka errelebantzia handirik ETAren existentzia mehatxu gisara bizi zutenentzat, eurentzat desegitearen albistea izan zelako mugarri, 2018an. Badu, ordea, garrantzia, euskal gizartearen sektore berri batentzat: 1990eko hamarkadaren amaieran eta 2000ekoaren hasieran jaiotako gazteentzat. Salbuespenak salbuespen, gatazkaren garai armatu eta biolentoenari buruzko oroitzapen zuzenik ez daukan belaunaldi bateko kideak dira gazteok; 2019. urte honetan, hain zuzen ere, helduarora iristen ari direnak. Gatazka armatua lehen pertsonan bizi izan ez duen lehenbiziko heldu belaunaldiaren aurrean gaude, beraz; Euskal Herriko historiaren zati horri buruzko ezagutza, diskurtso eta jarrerak besteen esperientzietan eta haien kontakizunetan oinarrituta eraiki dituena ezinbestean.

Testuinguru horretan, geroz eta maizago agertzen ari den kezka da memoriaren transmisioarena: gatazka armatuaren inguruko zein narratiba ari zaizkie iristen hurrengo belaunaldiei, eta zein kanalen bidez (Euskadiko Gazteriaren Kontseilua, 2018). Gaiari buruzko testuinguru diskurtsibo konplexuan hazten ari dira gazteok. Alde batetik, gatazkaren beraren izaera auzitan jartzen duten gatazka diskurtsibo ugari presente daude oraindik hedabideetan eta esparru politikoan; Hego Euskal Herrian bederen, badago oraindik gaiari buruzko tabu sentsazioa gazteen artean (Velte, 2018): diskurtso ofizial askotan ere, gatazkaren irudikapen polarizatu bat eraikitzen da oraindik (Velte, 2016).

Etxeetan, aldiz, denetariko errealitateak daude. Guraso askok, indarkeriazko garaien ostean maiz gertatu ohi den bezala, gatazkaren alderdi bortitzenak ez transmititzearen aldeko hautua egin dute: seme-alabei gorrotoa edo trauma ez transmititzeagatik; zentsura edo arbuio diskurtsibo baten beldur direlako; edota, besterik gabe, ez daukatelako tresnarik edo ez diotelako aski garrantzia ematen euren esperientziak kontatzeari. Honen inguruko ikerketarik ez dugu ezagutzen Euskal Herrian; bai, ordea, nazioartean: AEBetan (Fivush, 2010), Balkanetan (Reidy et al., 2015) edo Ipar Irlandan (Devine \& Schubotz, 2010), esaterako.

Testuinguru horretan, hezkuntza arautua izan daiteke trauma edo ezintasun pertsonaletatik eta interes politikoetatik aparteko transmisio kanal nagusietako bat. Testuliburuak egia ukigarriak eskaintzen dizkiete eskolaesparrutik kanpo informazio zatikatua, inkoherentea edo liskartsua baino eduki ez dezaketen ikasleei (Velte, 2018). Alabaina, gaur-gaurkoz ez da sortu gaiari zuzenean heltzen dion material didaktikorik. Hego Euskal Herriko ikastetxeetako Historia edo Gizarte gaietako testuliburu gehienetan, material teorikoaren eduki garrantzitsuenak 1978. urtera arteko epea har- 
tzen du aintzat, frankismo osteko Trantsizioa erreferentzia gisara hartuta. Horren ondorengo hamarkadetako garai armatuak, ordea, apenas hartzen duen lekurik material didaktikoan, eta tokian tokiko errealitatearen eta irakasleen interes eta inplikazio pertsonalaren menpe geratzen da maiz garai horri buruzko datuen azalpen eta transmisioa. Ondorioz, gerta liteke - eta gertatzen ari da - toki batzuetako ikasle nerabeek garai armatuari buruzko informaziorik ia ez edukitzea. Areago: gaur egun hezkuntza sistemara sartzen ari diren irakasle gazte asko ere gatazka armatuari buruzko oroitzapen zuzenik gabeko belaunaldiko kideak dira dagoeneko. Memoriaren transmisioaren katean, puntu horretantxe has daiteke jarioa eteten: memoria transmititu behar duten irakasleek ere ez daukatenean aski tresnarik memoria hori euren ikasleei helarazteko.

Testuinguru horretan sortu zuen Eusko Jaurlaritzak Herenegun programa didaktikoa. 2018ko ekainean aurkeztu zuten lehenbiziko aldiz Giza Eskubide, Bizikidetza eta Lankidetzaren Idazkaritza Nagusiak, Hezkuntza Sailak eta Gogora fundazioak, urte horren amaieran Arabako, Bizkaiko eta Gipuzkoako zortzi ikastetxetan programa pilotu gisara abiatzeko asmoz. Unitate didaktikoak 1960 eta 2018 arteko «Memoria Hurbila» zeukan ikergai, eta DBHko bigarren eta laugarren mailako curriculumean txertatzeko diseinatutako lau liburukik osatzen zuten. Lehenbizikoan, material didaktikoaren laburpen-testu bat zetorren, irakasleek informazio hori eskura izan zezaten; beste bi koadernotan, eduki horiek ikasgelara eramateko ariketak eta bestelako proposamen metodologikoak laburtzen ziren batik bat; eta azken koadernoan, irakasleentzako testu historiko osagarri batzuk agertzen ziren.

Programaren aurkezpenak zalaparta eragin zuen eremu politikoan (Goikoetxea, 2019): une hartan gobernuan zegoen EAJk ez beste alderdi guztiek kritikatu zuten. Batzuek ETAren indarkeria aski ez gaitzestea leporatu zioten; besteek, kontakizun «interesatu eta ideologizatua» egitea eta gatazkaren biktima mota batzuk soilik kontuan hartzea. Azkenean, unitate didaktikoaren sustatzaileek eurek onartu zuten ez zegoela hura martxan jartzeko baldintza egokirik, eta eperik gabe atzeratu zuten haren inplementazioa, gaiaz «gogoeta» sakonagoa egiteko promesarekin. Auziak agerian utzi zuen zenbateraino den oraindik gai sentsiblea gatazkaren memoriarena. Jonan Fernandez Bake eta Bizikidetza idazkariak berak nabarmendu zuen eskola-materiala sortzeko zailtasun handienetako bat zela gatazkaren historiari buruzko «kontakizun partekaturik» ez egotea (Goikoetxea, 2019, 3. or.).

Ikerketa-lan honetan, adiskidezearen ikuspegitik aztertuko ditugu $\mathrm{He}$ renegun programak proposatu zituen edukiak, Johan Galtungen gatazken teoriatik abiatuta. Defendatuko dugunez, biolentziazko etapa baten osteko deseskalatze- eta adiskidetze-prozesuek ezinbestean eskatzen dute gizarte horretako diskurtso eta iruditeria nagusien egokitzapena, ez derrigor narratiba partekatu bakar bat sortze aldera, baizik eta, hain zuzen ere, narratiben aniztasuna onartze eta ikusarazte aldera. 


\section{IKERKETAREN HELBURUAK}

- Helburu nagusia: Herenegun unitate didaktikoak, hezkuntzako diskurtso gisara, Johan Galtungen eta John Paul Lederachen baketze ikuspegiaren printzipioak betetzen dituen edo ez aztertzea.

- Helburu zehatzak:

1. Unitate didaktikoan euskal gatazka eta euskal gai terminoen erabilera aztertuta, biolentzia armatuzko garaiari buruz eta haren jatorriari buruzko makronarratibak identifikatzea.

2. Gatazka horretan inplikatutako aktore nagusiei buruzko narratibak eta euren karakterizazioa aztertzea: eragile armatuak eta biktimak.

3. Unitate didaktikoan nabarmentzen diren bake iniziatiben inguruko diskurtsoak aztertzea.

\section{OINARRI TEORIKOAK}

Lan honetarako, Johan Galtungen (2003) gatazken eraldaketarako teoria erabili dugu oinarri gisara, eta, neurri txikiagoan, John Paul Lederachen (1998) ikuspegia. Bi autoreek argudiatzen dutenez, gatazkak gizarte baten berezko ezaugarrietako bat dira, modu egoki eta ez-biolentoan eraldatu ezean, batzuetan, adierazpen biolentoak har ditzaketenak. Teoria horien arabera, gatazka batek hainbat geruza edo dimentsio ditu: zuzenekoa - ukigarria, biolentzia fisikoarekin zerikusia duena-, egiturazkoa - gatazkaren oinarrian dauden interes-desoreketatik eratorria - eta kulturala - aurreko biak justifikatzen eta legitimatzen dituen alderdi nagusiki diskurtsiboa-. da:

Gatazka bat sakoneran ulertzeko, beraz, geruzaz geruza aztertu behar

«(...) we ask the same question as for disease: what happened before violence, the intended hurt and harm to human beings? Before aggression, including the inner aspect, the hatred (..) of some Other, even of oneself? Answer: polarization, with dehumanization of Other (...) untransformed conflict, a problematic relation rather than a problematic actor; person, nation, state.» (Webel eta Galtung, 2007, 15. or.)

Gatazken sorreran zein haien konponbidean, bertan inplikatutako aktoreen arteko harremanetan edo harreman faltan jartzen du fokua ikuspegi honek. Horren arabera, gatazka armatuei bake negatibo bat kontrajar dakieke, edo bake positibo bat.

Bakearen ikuspegi negatiboa elikatzen da bakea soilik biolentziarik ezaren moduan ulertuta. Eredu hau segurtasunaren ideian oinarritzen da, 
baina funtsean polarizazio kultural eta identitarioa - eta, ondorioz, konfrontaziozko eskemak - aldatu gabe: bake mota horretan, Beste aldeak beti jarraituko du bakerako traba izaten, eta ez da aintzat hartuko aldeen arteko helburu bateratu posiblerik. Bakearen ikuspegi positibo batek, aldiz, interes kontrajarrien arteko gatazka baten moduan ulertzen du gatazka, eta irtenbidea ez du aldeetako baten helburuen deuseztapenean ikusten (garaipenaren eredua), baizik eta gatazkaren beraren «eraldaketa enpatiko, kreatibo eta ez indarkeriazkoan» (Webel eta Galtung, 2007, 10-15. or.). Kreatibitatea, Galtungen (2013) hitzetan, gatazkak berak sortu eta indartutako buruko eskemak gainditzea da (60. or.): erabateko etsai kategoriara murriztutako Beste hura humanizatu eta haren jarduteko arrazoiak ulertzea.

Baketzeak edo adiskidetzeak, beraz, osagai diskurtsibo garrantzitsu bat dauka deseskalazio edo despolaritzatze-ikuspegi horretatik begiratuz gero: Besteari buruzko diskurtsoak eta irudiak malgutzeko eskatzen die gatazkan nahastutako aktoreei. Hain zuzen ere, bakearen eraikuntza diskurtsibo horretan, ezinbesteko rola jokatzen dute memoria kolektiboa eraikitzen duten dispositiboek; komunikabideek eta material didaktikoak, besteak beste. Eurek legitimatzen dituzte, neurri batean, gatazka baten historiari buruzko narratiba jakin batzuk, eta memoria hori erreproduzitzen dute transmisiorako gailu bihurtuta. Transmisio hori hizkuntzaren bidez egiten da gehienetan: gertakari bat zuzenean bizi izan ez duen pertsona batek beste batzuen kontakizunaren bidez berreraikitzen du gertakari horri buruzko bere buruko eredua (Van Dijk, 2003), gertakari horri buruzko datu, iritzi eta jarrerez osatua. Gunther Kressek (2011) azaltzen duenez, ikasleak, informazio berri bat jasotzen duenean, bere aldez aurretiko ezagutzekin lotzen eta osatzen du. Informazio horretatik gutxi dagoenean, eragin handiagoa izan dezakete mezu zehatzek. Areago: Lederachek (1998) ohartarazten duenez, oso polarizatuta dauden gizarteek manipulazioa sufritzeko arrisku handiagoa dute, etsaiaren irudia errotuta dagoenean erraza delako «propaganda supiztailea» egitea komunitatearen koherentziaren izenean (39. or.). Horren aurka, estrategia despolarizatzaileak proposatzen ditu gizarteko diskurtso nagusiak ezartzen dituzten kanaletan.

Bakearen ulermen holistiko horren arabera orientatuta dagoen hezkuntza batek ere helburutzat izan behar luke ikasleek euren testuinguru sozial eta politikoa ikuspegi eraldatzaile batetik ulertzeko gaitasuna izatea. Horretarako, ahots aniztasuna eta ezberdinen arteko elkarrizketa dira gakoetako bi, Cabezudok eta Haavelsrudek (2007) argudiatzen dutenez:

Peace education needs a dialogical, communicative rationality and the acts of knowing and thinking are directly tied to one another as knowledge requires communicative expression (Morrow and Torres 2004: 69). Dialogue does not exclude the conflict as truth does not come from the conformation of my vision with the vision of 'the other'. (286. or.) 
1. taula

Bake narratibak eta gerra narratibak (Webel \& Galtung, 2007)

\section{$\frac{\text { Bake narratibak }}{\text { I. Bakerantz/gatazkarantz orientatua }}$}

- Gatazkaren sorrera esploratzen du.

- Hainbat alderdi, helburu eta auzi (issue) bereizten ditu. Denek irabaz dezaketen ideiak orientatzen du.

- Esparru guztietan bilatzen ditu kausak eta ondorioak, baita historian eta kulturan ere.

- Alde guztiei ahotsa eman eta guztiak humanizatzen ditu, ez soilik norberarena. Enpatia eta ulermena sustatzen ditu.

- Gatazka edo gerra ikusten du arazo gisara.

- Biolentziaren efektu ikusezinei arreta jartzen die (traumak eta loriak, egiturazko kalteak).

\section{Pertsonetarantz orientatua}

- Alde guztien sufrimenduari eskaintzen dio arreta.

- Kolektibo gutxituei ahotsa ematen die.

- Bakea sustatzen duten pertsonei ematen die arreta.

\section{Konponbiderantz orientatua}

- Bakea $=$ biolentziarik eza + kreatibitatea.

- Bake iniziatibak nabarmentzen ditu.

- Biolentzia gehiago eragozteko, egituran eta kulturan ipintzen du arreta.

- Gatazka biolentoaren osteko faseari jarraipena egiten dio: berreraikuntza eta adiskidetzea.
Gerra narratibak

\section{Biolentziarantz orientatua}

- Gatazkaren gertalekuan (arena) jartzen du arreta: espazio horretan bilatzen ditu kausak eta ondorioak (nork bota ote zuen lehen harria), azpiko faktoreetara jo gabe.

- Bi alde eta helburu bakarra bereizten ditu (irabaztea). Zero-sum orientation (soilik batek irabaz dezake).

- Gu vs. Haiek/Besteak kategoriatan oinarritutako kontakizunak. Beste aldea deshumanizatzen du.

- Gure aldeari ahotsa ematen dio: Haiek/Besteak ezabatu beharreko arazo gisara ikusten ditu.

- Biolentziaren ondorio ikusgarriei soilik ematen die arreta: hildako, zauritu eta kalte materialak.

\section{Eliteetaranz orientatua}

- Gure aldearen sufrimenduari ematen dio arreta.

- Ahotsa eliteei eta haien barruko bakegileei ematen die.

\section{Garaipenerantz orientatua}

- Bakea = garaipena + su-etena .

- Bake iniziatibak aintzat hartzen ditu, baldin eta garaipena bere eskura ikusten badu.

- Maila instituzionaleko eta gizartearen eremu arautuetako akordioetan jartzen du arreta.

Esan genezake, beraz, testuliburuen zereginetako bat ere badela, gatazka armatuaren osteko adiskidetze fase honetan, gatazkak berak sortutako buruko eskema polarizatuak leuntzen laguntzea, baketze ikuspegi po- 
sitibo batetik. Eskola materiala etengabeko dialektikan dago gizarte bateko diskurtso eta narratiba nagusiekin, eta, bereziki belaunaldi berrientzako transmisiora begira, eragin handia du diskurtso horiek moldatzeko edo finkatzeko garaian (Cabezudo eta Haavelsrud, 2007).

Nola bultza daiteke ikuspegi despolarizatzaile eta adiskidetzaile bat material didaktikoaren bidez? Gure ustetan, Galtungek kazetaritzarako emandako proposamen gehienak aplika dakizkieke eskola-eremuko diskurtsoei ere, haiek ere gatazka bat hizkuntzaren bidez berreraikitzen dutela kontuan hartuta. Galtungek bake-kazetaritza eta gerra-kazetaritza terminoak darabiltza gatazka egoeretan hedabideetan egin daitezkeen aukera diskurtsibo eta narratiboak sailkatzeko (Galtung, 2003, 97-98. or.), baina, ikuspegia zabalduta, bake narratibez eta gerra narratibez ere hitz egin genezakeela uste dugu. Honela laburbilduko lirateke:

Printzipio horiek ezagututa, errazagoa zaigu material didaktikoak baketzea ikuspegi kreatibo eta deseskalatzaile batetik sustatzen ote duen behatzea, eta, ondorioz, etorkizunean diseina daitezkeen material pedagogikoetarako proposamen egoki batzuk egitea.

\section{METODOLOGIA}

Ikerketa kualitatiboa eta partez kuantitatibo honetan, diskurtsoaren analisia erabili dugu Herenegun unitate didaktikoaren lehenbiziko bertsioa aztertzeko. Zehazki, 2018ko ekainean aurkeztutako materialen artetik, lehenbiziko koadernoaren edukia aztertu dugu: 11 orrialdeko testu jarraitu bat eta haren eranskinak — bost orrialdeko kronologia bat, 1960tik 2018ra doana, eta gatazkaren historian garrantzitsutzat jotako elementuen irudikapen eskematiko batzuk - . Programa osoko zati esanguratsuena da lehenbiziko koaderno hori, irakasleentzako material teorikoa dakarren bakarra delako, eta, ondorioz, eduki aldetik mamitsuena; gainerako koadernoak metodologikoagoak direlako baztertu ditugu azterketa honetarako.

Analisi fasean, diskurtso idatziaren geruza edo maila ezberdinetatik identifika daitezkeen esanahiak hartu ditugu kontuan: maila makrolinguistikoa - esaldien antolaketatik zein erabilitako metaforetatik inferitu daitezkeen esanahiak - zein mikrolinguistikoa - hitz eta adierazpideen aukeraketa eta osaera zehatzetik ondoriozta daitezkeenak - aztertu ditugu hartara. Horretarako, gure helburuen araberako lau analisi-kategoria bereizi ditugu, eta haien arabera kodifikatu dugu aztertutako testua:

1. Gatazka: kategoria honetan, euskal gatazkaren beraren definizioak aztertu ditugu, gainerako informazio guztia enmarkatzen duen testuingurua finkatzen duelako hark. Besteak beste, haren izateko arrazoiei, garapenari eta inflexio puntutzat jotako elementuei erreparatu diegu. 
2. Aktoreak: gatazkan nahastutako aktore nagusiak nola erretratatzen diren behatu dugu. Besteak beste, zein ekintza eta ezaugarri egozten zaizkien, zein izen konkretu agertzen diren haien ordezkari gisara, eta nola deskribatzen diren euren arteko harremanak.

3. Biktimak: Gatazkak eragindako biktimen inguruko azterketa atal beregain gisara behatzea erabaki dugu, «alde bateko zein besteko biktimen» eskema itxia ez elikatzeko asmoz. Errealitate soziala poliedrikoa dela abiapuntu harturik, ez dugu uste talde edo erakunde zehatz baten biktima izateak automatikoki inor bi kategoriatako batean sartzea ahalbidetzen duenik. Beraz, biktimak kategoria beregain gisara aztertuko ditugu, talde horretan aniztasun ideologiko handia dagoela aintzat hartuz.

4. Bakea: Gatazkarekin bezalatsu, bakearen definizioari erreparatu diogu; hala nola, bakegintzan jardun duten eragileen erretratazioari. Atal honetan, bereziki interesatzen zaiguna da bakearen definizioak ikertzea, horiek gero Galtungen bakegintzaren ikuspegiarekin alderatzeko, eta ikusteko, besteak beste, bake positibo baten irudia sustatzen den edo bakea soilik segurtasunezko ikuspegi batetik ulertzen den.

Aztergaia Nvivo softwarea erabiliz kategorizatu dugu. Aipatutako elementuetan arreta berezia jartzeaz gain, haiek diskurtsiboki antolatzeko estrategia eta baliabide linguistikoei ere erreparatu diegu; sarritan, horietatik esanahi gehiago ondoriozta daitezkeelako. Estrategia horietako batzuek Wodakek garatutako ikuspegi diskurtsibo-historikoan dute jatorria (Van Leuwen \& Wodak, 1999). Estrategia diskurtsiboak «ekintza linguistikoak» gisara definitzen dituzte autoreok, eta honakoak zerrendatzen dituzte (92-111. or):

1. Estrategia eraikitzaileak: taldeak edo bandoetan oinarritutako kategoriak diskurtsiboki ezartzeko eta definitzeko balio dutenak dira. $G u$ eta Besteak dira kategoria horietako nagusiak.

2. Iraunarazte eta justifikazio estrategiak: diskurtsoan eraikitako edo finkatutako identitate eta kategoria horiek mantentzeko eta erreproduzitzeko erabiltzen direnak; arrazoi moralak, datuak edo bestelako argudioak izan ohi dira.

3. Transformazio estrategiak: finkatutako egoera bat eraldatzea helburu duten estrategiak dira, adibidez, zerbait birformulatuta. Informazioaren elipsia, berrantolaketa, ordezkapena edo gehikuntzen bidezko legitimazioa izan daitezke. Gehitutako informazio honek autorizazioaren, arrazionalizazioaren edo ebaluazio moral inplizituaren bidez erantsi diezaioke legitimazioa esaten denari.

4. Deuseztatze estrategiak: indarrean den statu quo bat desegitea helburu duten estrategiak dira; oposiziozko diskurtsoetan ageri dira gehienbat. 
Estrategia horiek esanahi orokor edo makronarratibak inferitzea ahalbidetzen digute (Van Dijk, 1990), oinarrizko mekanismo batzuen bidez: aurrez emandako informazio inplizitua (aurresuposizioak); adierazpenaren beraren esanahitik bertatik ondoriozta litekeen informazioa (inplikazioa); eta pragmatikaren bidez, testuingurutik osatzen den esanahia (inplikatura).

\section{EMAITZAK}

\subsection{Euskal gatazkaren irudikapena}

Herenegun unitate didaktikoaren edukiak aztertzerakoan, arreta berezia ipini diogu euskal gatazka bera eta haren jatorria azaltzeko erabiltzen diren estrategia eta baliabide linguistikoei, ikasleei gatazka politiko eta armatua zein testuingurutan kokatzen zaien jakiteko; izan ere, horrek gainerako irakurketetako asko baldintza ditzake.

Aztertutako testuak lau bider baino ez du erabiltzen gatazka hitza guk darabilgun testuinguruan (Euskal Herriaren naziotasunaren inguruko gatazka politiko, ideologiko eta armatua). Horren ordez, maizago ageri dira «euskal gaia» bezalako termino orokortzaileak, gaztelaniaz sarritan erabiltzen den la cuestión vasca-ren baliokideak. Aukeraketa semantiko horrek karga politikoa kentzen dio izendatutako elementuari: gatazka baten aitortzak interes-gatazka bat onartzea dakar ezinbestean, helburu eta motibazio zehatz batzuekin jokatzen duten bi eragile edo gehiagoren arteko tentsio bat. Gatazka terminoaren inguruko lehia hori nabarmena da gaur egun esparru politikoan eta komunikatiboan, eta material didaktikoan topatutako erreferentziek ere horren oihartzuna jaso dutela ondoriozta genezake.

«Gatazka» eta «euskal gai» bezalako terminoen erabilerari erreparatuta, hiru narratiba nagusi identifikatu ditugu:

\subsubsection{Erreakzio kontserbadorearen narratiba: «Euskal gatazka gatazka identitario bat da»}

Unitatearen kontakizunak ETAren sorrera du abiapuntu, eta, funtsean, frankismo garaian Hego Euskal Herrian gertatutako aldaketa sozial eta ekonomikoen aurkako erreakzio identitario eta kultural baten moduan aurkezten du talde horren jardun armatua:

ETA testuinguru honetan sortu zen:

a) Francoren erregimenak sortutako egoerari erantzuteko (askatasun demokratiko eza, euskal nazionalismoaren, euskararen eta euskal kulturaren aurkako errepresioa; eta erdalduntze eta erabateko kultura-asimilaziorako politika). 
b) 1950-1975eko industrializazio-prozesuak zekarren deseuskalduntze-mehatxuari erantzuteko. (4.or.)

Pasarte honetan aipatutako arrazoiez gain, Xx. mendean Espainiatik Euskal Herrirantz izandako migrazio-prozesuak ere aipatzen dira zeharka atal berean. Beha daitekeenez, zerrenda horretan pisu handiena euskarari eta euskal identitateari lotutako elementuek dute; askatasun demokratikoak behin soilik aipatzen dira, gehiago zehaztu gabe. Ondorioz, euskal identitatea eta euskara arriskuan ikustearen ondorio gisara aurkezten da euskal gatazka: identitate kasik etniko bat arriskuan ikusten dutenen erreakzio kontserbadore bat, soilik eurei dagokiena eta eurei ardura zaiena.

\subsubsection{Botere lehiaren narratiba: «Euskal gatazka interes politikoen arteko gatazka bat da»}

Identifikatutako bigarren narratiba nagusian, «euskal gai edo gatazka» delakoari — testuak berak darabiltza sinonimo gisara - izaera politikoagoa aitortzen zaio: «nazio arazoa»-rekin lotzen da, eta hark «autogobernuarekin» zerikusia duela iradokitzen da - guztiak ere distantzia adierazten duten kakotxez nabarmenduta-, esplizituki euren arteko kausa-efekturik eraikitzen ez den arren. Hartara, gatazka identitario, etniko, kultural eta linguistiko batetik interes politikoen esferara igarotzen da kontakizuna (interes politikoak gobernantzarekin eta boterearekin zerikusia duten interes gisara ulertuta). Gatazka-guneak ez dira lotzen hizkuntzarekin, baizik eta Euskal Herria politikoki egituratzeko moduarekin: «lurraldetasuna», «erabakiaren subjektua» eta «subiranotasun politikoa» ditu mintzagai testuak. Inplizituki, gatazka Euskal Herria Espainiar zentralismotik gobernatu nahi dutenen eta hura modu burujabean gobernatu nahi dutenen artekoa dela ulertarazten da, azken hauen artean bi jarrera posible egonik: egungo autogobernuarekin konforme daudenak eta burujabetza handiagoa nahi dutenak.

Testuak, egituraketa horretan, ulerkera-marko espainiar bat elikatzen $\mathrm{du}$, alderdi «nazionalistak» eta «ez-nazionalistak» bereizten dituenean: nazionalismoaren etiketa soilik alderdi abertzaleez mintzatzeko erabiltzen du, espainiar nazionalismoari erreferentzia argirik egin gabe. Aukeraketa linguistiko hori hierarkizazio baten adierazpen diskurtsiboa da: nazionalismoa, oro har, konnotazio negatiboak dauzkan terminoa baita. Testu honek alderdi ez-nazionalista gisara kategorizatzen dituen PP eta PSOE, nazionalista gisara kategorizatutako EAJ, EA eta ezker abertzalea bezain nazionalistak dira euren lurraldetasun-erreferentzietan eta erreferentzia politikoetan, bakoitzak nortasun nazional edo kultural banatan oinarritutako eremua duelako subjektu politikotzat, eta marko horretan jarduten duelako. Testuinguru horretan, adjektibo faltak hegemonia bat adierazten du: eredu nagusia neutroa da, bere horretan legitimatzen da, deskribapenerako beharrik gabe. Bestea da nabarmentzen dena. 


\subsubsection{Motibazio politikorik gabeko gatazkaren narratiba: «ETA bera da gatazka»}

Hirugarren narratiba nagusiak ETAren jarduera armatua jartzen du erdigunean, eta gatazka eragitea erakunde horri egozten dio. Beste era batera esanda: euskal gatazka existitzen da ETA existitu den bitartean, jarduera armatua abian zen bitartean. Narratiba honetan, testuinguruko elementuek garrantzia galtzen dute eta aldeen motibazio politikoa ere bigarren mailako elementu bihurtzen da; eta, ondorioz, bakea, gatazkaren amaiera, ETAren amaierarekin parekatzen da.

Honako pasarte hauek elikatzen dute narratiba hau:

ETAren estrategia terroristak ezinezkoa bihurtu zuen bakea. (6.or)

Espero zitekeen diktaduraren ostean, demokraziarekin, Euskadi autonomia-erkidego bihurtuko zela eta horrek berehala ekarriko zuela bakea eta normalizazioa. Ez zen, baina, horrela gertatu. ETA eta hark sortutako gatazka izan ziren Espainiako demokrazia berriarentzat aurre egin beharreko arazo nagusia. (5.or)

Oso esanguratsuak iruditu zaizkigu Trantsizioari buruzko pasarte hauek, ETA bera berdintzen dutelako gatazkarekin. Diskurtso honek talka egiten du ikuspegi inklusiboago batekin, non ETAren jarduera armatua lehendik zegoen gatazka sakonago baten adierazpen biolento gisara ulertzen den. Gure ustez, ikuspegi hau erabilgarriagoa da gatazkaren ertzak eta sakoneko inplikazioak ulertzeko, eta epe luzera egitura sozial eta kulturaletan eragina duten irtenbideak proposatzeko.

Aldiz, material didaktiko honetan eraikitzen den narratiba polarizatzailea da; ETAren existentzia eta jarduera gatazkaren existentziarekin berdinduz, ezabatu beharreko etsaiaren ideia elikatzen du. Haren erretratu demonizatzaile bat elikatzen da, azaldu gabe zein arrazoik bultzatu zituzten ETA eta gizartearen sektore bat Trantsizioarekin kritiko izatera. Galtungen printzipioen arabera, halako alderaketek diskurtso polarizatzaile eta demonizatzaileen moduan funtzionatzen dute, helburu posible bakarreko eskemak elikatuz (zero-sum orientation, soilik batek irabaz dezake, eta horretarako beharrezkoa da Bestearen porrota erabatekoa izatea): ETA edo bakea, ez dago besterik. Edo, inplizituki inferitu daitekeenez: bakerako, ETAk desagertu beharra dauka. Kasu honetan, «arazo» hitzaren erabilerak posizionamendu argia adierazten du zuri-beltzeko paisaia horretan. Irakurlearen ikuspegitik, «arazoa» ETA bada, gu (barne-taldea, ingroup) kategoria beste muturrean kokatzen da, ondorioz, bi muturreko eskema bat elikatuz. Galtungen baketze printzipioen arabera, beraz, gerra narratiben artean kokatuko genuke pasarte hau. Jarraian, bake narratiba alternatibo batzuk proposatzen ditugu: 
2. taula

Identifikatutako estrategiak eta proposatutako narratibak

\begin{tabular}{|l|}
\hline \multicolumn{1}{|c|}{$\begin{array}{c}\text { Identifikatutako narratiba } \\
\text { polarizatzaileak }\end{array}$} \\
\hline $\begin{array}{l}\text { «ETAren biolentzia eta ETA } \\
\text { bera dira gatazka» }\end{array}$ \\
\hline $\begin{array}{l}\text { Eskema demonizatzailea: «ETA } \\
\text { vs. bakea» } \\
\text { - Eskema honetan, denon in- } \\
\text { teresen aurkakoa da beste al- } \\
\text { dearen jarduna. }\end{array}$ \\
\hline Bakea: etsaia (ETA) ezabatzea \\
\hline
\end{tabular}

\begin{tabular}{|l|}
\hline Proposatutako narratiba inklusiboak \\
\hline $\begin{array}{l}\text { «Gatazkak erro sakonak dauzka, } \\
\text { eta biolentzia da haren adieraz- } \\
\text { penetako bat, ez delako modu } \\
\text { kreatiboan garatu» }\end{array}$ \\
$\begin{array}{l}\text { Alde eta interes desberdinak iku- } \\
\text { sarazten dituen eskema: «ETA } \\
\text { vs. beste eragile batzuk, nor bere } \\
\text { helburu eta interesekin» }\end{array}$ \\
$\begin{array}{l}\text { Bakea: gatazkaren sakoneko ga- } \\
\text { rapen kreatibo bat adierazpen ez- } \\
\text { biolentoetara }\end{array}$ \\
\hline
\end{tabular}

Aipatutako irudikapen horrek bi mekanismo ditu oinarrian: gatazkaren ñabardura eta konplexutasunak ezabatuta eta hura funtsean elementu bakar batera murriztuta (ETAren existentzia eta haren jarduera armatua), eskema sinplista eta dikotomikoak elikatzen dira: polarizatzaileak, finean. Horren gainean eraikitzen dira gatazkari buruzko gainerako narratiba guztiak.

ETA baldin bada arazoa, eta haren aurkakoa ez badira beste eragile batzuen interesak, baizik eta «bakea» bere osotasunean, funtsean gizarte osoaren interesen aurkako elementu gisara aurkezten zaigu aktore bakar baten existentzia eta jarduna. Ideia hau beste zenbait pasarterekin indartzen da, zeintzuek ETAren sinesgarritasuna eta babes soziala ezdeus gisara erretratatzen baitute. Miguel Angel Blanco Ermuko (Bizkaia) zinegotziaren bahiketaren eta hilketaren harira agertzen den pasarte hau argigarria da:

«Terrorismoaren aurkako halako katarsi kolektiboa izan zen, eta herritarren matxinada, une zehatz batzuetan ETA eta bere inguruari ez ezik, nazionalismo osoari zuzendua zirudiena.» (8. or.)

Pasarte honetan ere antzeman daiteke lehen aipatutako karratu polarizatzailea. Alde batean ETA legoke, terrorismo eta nazionalismo kontzeptuekin lotuta; biak ala biak, konnotazio negatibodunak eta demonizatzaileak - terrorista adjektibo esentzialista bat da, motibazio politikoa ukatu 
eta, ondorioz, arrazoiaren bidez negoziatzeko gaitasunik aitortzen ez diona hura daraman aktoreari-. Beste aldean leudeke Bakea, herritarrak (ezabertzale gisara kategorizatutakoak) eta biktimak.

Esanguratsua iruditu zaigu, halaber, testuak zuzenean eta kakotxik gabe erreproduzitzen duela «ETA eta bere ingurua» topos edo esaldi egina. Erreferentzia interdiskurtsibo bat da, marko espainiar baten testuinguruan erabili ohi den esaldi egin bat delako: Beste bandoaren ideia indartzen duen estrategia orokortzaile bat da.

Azkenik, esanguratsua da nola deskribatzen diren herri mobilizazioak, deitzaileen arabera:

a) ETAren aurkako manifestazioak direnean, «herritarren matxinada» erabiltzen da: konnotazio positibodun adierazpen legitimatzaile bat.

b) Manifestazio abertzaleak direnean, intimidazioaren ondorioz eta beldurra sortzeko asmoz egindako mobilizazioak dira:

«(...) «ETAren ingurua» deiturikoek bultzatutako eta gauzatutako mobilizazio eta kale-indarkeriarekin (hau da, kontramanifestazioak, autobusak erre, instalazio eta eraikin esanguratsuak suntsitu, erasoak). Beldurrarazteko modu bat zen.» (8. or.)

Azken pasarte hau eta aurretik aipatutakoa elkarrengandik oso gertu ageri dira unitate didaktikoan. Bien artean eskema polarizatzaile bat elikatzen dute, alde baten mobilizazioak goretsiz eta bestearenak demonizatuz.

\subsection{Gatazkan inplikatutako aktoreak eta haien irudikapena}

Aurreko atalean identifikatutako banaketa binarioari jarraikiz, testuak nagusiki bi «bando» bereizten dituela ondoriozta dezakegu: alde batetik, ETA bera - hura da kontakizunaren erabateko protagonista, gehien eta xehekien erretratatuta agertzen den aktorea, zalantzarik gabe - eta «haren ingurua»; eta, bestetik, haren aurkako alderdi, erakunde eta eragileak. Gatazkaren irudikapenaren oinarrizko joko-zelaia, oinarrizko kategoriak ezartzeko balio duen estrategia eraikitzailea da. Jarraian, xehekiago aztertuko dugu nola deskribatzen dituen aktore nagusi hauetako bakoitza. Horretarako, Van Dijken (1990) inferentzia kontzeptua darabilgu, egitura mikrolinguistikoetatik ondoriozta litezkeen makroegiturei edo esanahi orokorragoei buruz hitz egiteko. 


\subsubsection{ETAren irudikapena}

3. taula

\section{ETAren irudikapena}

\begin{tabular}{|c|c|c|}
\hline & Topatutako adierazpenak & Inferitutako ideiak / Behatutako berezitasunak \\
\hline \multirow{4}{*}{$\begin{array}{l}\text { Deskribapenak } \\
\text { (adjektiboak, } \\
\text { azalpenak, } \\
\text { etab.) }\end{array}$} & $\begin{array}{l}\text { «Indarkeria terrorista». }(5 . \text { or.) } \\
\text { «Desgaste-terrorismoa». }(6 . \text { or.) } \\
\text { «Terrorismoa, indarkeria» }(6 . \text { or.) }\end{array}$ & $\begin{array}{l}\text { Talde terrorista. Uneren batean «euskal } \\
\text { erakunde independentista» erabiltzen } \\
\text { den arren, oro har ugariagoak dira haren } \\
\text { izaera biolentoa - ez soilik ekintza bio- } \\
\text { lentoak, izateko modu berezkoa baizik- } \\
\text { nabarmentzen duten izendapenak. }\end{array}$ \\
\hline & $\begin{array}{l}\text { «ETAk ez zuen onartzen bere plan- } \\
\text { teamenduetatik inolaz ere aldentzea» } \\
\text { (6. or.) }\end{array}$ & Zurruntasuna \\
\hline & $\begin{array}{l}\text { «Europako lehen faxisten indarkeria 'es- } \\
\text { kuadrista' gogorarazten zuena» (8. or.) } \\
\text { «Beldurraren presioa euskal gizartearen- } \\
\text { gan» } 6 \text {. or.) }\end{array}$ & $\begin{array}{l}\text { Jarrera autoritarioa. Bilatutako intimi- } \\
\text { dazioa. }\end{array}$ \\
\hline & $\begin{array}{l}\text { «Euskadin, bizitzaren aurkako eskubi- } \\
\text { deen bortxaketa erabili zuen eragilerik } \\
\text { nagusiena eta handiena» ( } 26 . \text { or.) }\end{array}$ & Biolentziaren erruduna \\
\hline Helburuak & $\begin{array}{l}\text { «'Borroka armatu' hori Euskal Herria- } \\
\text { ren 'askapena' eta independentzia lor- } \\
\text { tzeko estrategiaren oinarrizko tresna } \\
\text { bihurtu zen» }(4 . \text { or. })\end{array}$ & $\begin{array}{l}\text { Perifrasirako erabilitako kakotxek esal- } \\
\text { diaren edukiarekiko distantzia adieraz- } \\
\text { ten dute. }\end{array}$ \\
\hline \multirow[t]{2}{*}{$\begin{array}{l}\text { Egotzitako } \\
\text { ekintzak }\end{array}$} & $\begin{array}{l}\text { «303 lagun hil zituzten } 1976 \text { eta } 1981 \\
\text { bitartean, eta } 4711982 \text { eta } 2000 \text { artean» } \\
\text { (6. or.) } \\
\text { «1980. urtea izan zen okerrena: } 96 \text { hil- } \\
\text { dako» (6. or.) } \\
\text { «Hipercor (...): } 21 \text { hildako eta } 46 \text { zau- } \\
\text { ritu» (6. or.) } \\
\text { «Kale borroka (...) } 310 \text { eraso» (9. or) } \\
\text { «J. Imaz Poliziaren komandantea hil zu- } \\
\text { ten» (6. or.) } \\
\text { «ETAren atentatu mortala Madrilen } \\
\text { Luis Carrero Blanco almirante eta Go- } \\
\text { bernuko presidentearen aurka.» (14. or.) }\end{array}$ & $\begin{array}{l}\text { Gatazkaren ondorio biolentoenetan } \\
\text { arreta handia jartzen da: hildakoak dira } \\
\text { gehien eta zehatzen ikusarazten direnak. }\end{array}$ \\
\hline & $\begin{array}{l}\text { «Noizbehinka herritarren artean gori ze- } \\
\text { goen gairen bat defendatu; Lemoizko } \\
\text { zentral nuklearraren aurkako borroka, } \\
\text { esaterako» }(6 . \text { or.) }\end{array}$ & $\begin{array}{l}\text { Oportunismoa, populismoa. Borondate } \\
\text { faltsua. }\end{array}$ \\
\hline
\end{tabular}




\begin{tabular}{|c|c|c|}
\hline & Topatutako adierazpenak & Inferitutako ideiak / Behatutako berezitasunak \\
\hline $\begin{array}{l}\text { Ordezkariak } \\
\text { (aurpegi } \\
\text { ezagunak eta } \\
\text { izen-abizenekin } \\
\text { aipatuak) }\end{array}$ & $\begin{array}{l}\text { «Txabi Etxebarrieta, hasierako ETAren } \\
\text { lider eta ideologo nagusia» (4. or.) } \\
\text { «Txikia, Argala, Mujika Arregi 'Ezke- } \\
\text { rra', Txomin Iturbe, Josu Ternera, Antton } \\
\text { Etxebeste» (5. or.) } \\
\text { «(..) sekula argitu ez den krimen ba- } \\
\text { ten ondorioz 1976ean Hendaian desa- } \\
\text { gertu zen Eduardo Moreno Bergaretxe». } \\
\text { (6. or.) } \\
\text { «Francisco Múgica Garmendia, J.L. Ál- } \\
\text { varez Santacristina eta José Arregi Eros- } \\
\text { tarbe» (8. or.) } \\
\text { «Mikel Antza, ETAko buruzagi politi- } \\
\text { koa, Soledad Iparragirre eta erakundeko } \\
\text { aparatu logistiko osoa» (12. or.) [bi izen } \\
\text { hauek hiru bider aipatzen dira: 8, 12 eta } \\
\text { 17. orrietan] } \\
\text { «I. Lopez Riaño» (8. or.) } \\
\text { «J. Urrusolo Sistiaga» (8. or.) } \\
\text { «Garcia Gaztelu 'Txapote', Josu Boli- } \\
\text { naga eta Jose Arizkuren Ruiz 'Kantauri' } \\
\text { (8. or.) } \\
\text { Atxilotutako ETAko kideak: «López } \\
\text { Peña 'Thierry', bake prozesuaren po- } \\
\text { rrotaren erantzulea, Garikoitz Aspiazu } \\
\text { ‘Txeroki' eta Aitzol Iriondo } 2008 \text { an; } \\
\text { Jurdan Martitegi eta Aitor Elizaran } \\
\text { 2009an; Ibon Gogeaskoetxea eta Mikel } \\
\text { Karrera Sarobe 'Ata' 2010ean; A. Zoba- } \\
\text { ran Xarla 2011n». (12. or.) }\end{array}$ & $\begin{array}{l}\text { - Ordezkari gehienak gizonezkoak dira; } \\
\text { bi emakumezko soilik ageri dira aipa- } \\
\text { tuta. } \\
\text { - Gehienak euren jardun deliktiboaren } \\
\text { testuinguruan ageri dira (atxiloketak } \\
\text { edo egozten zaizkien delituak). } \\
\text { - Batzuetan, ETAko kideen izengoi- } \\
\text { tiak erabiltzen dira; besteetan, ez, eta } \\
\text { ez da arrazoitzen zein den irizpidea. } \\
\text { Hipotesi posible bat da izengoitien } \\
\text { erabilerak areagotu egiten duela per- } \\
\text { tsonaien aurkezpen demonizatzailea, } \\
\text { haien pertsonaren alde militantea na- } \\
\text { barmentzen delako hartara, eta euren } \\
\text { alde humanoa, izen-abizen arrunte- } \\
\text { koa, lausotzen delako. } \\
\text { - Bereziki esanguratsua da, alde ho- } \\
\text { rretatik, Josu Uribetxeberriari 'Josu } \\
\text { Bolinaga' deitzeko erabakia, haren } \\
\text { bigarren abizena soilik erabiliz; Es- } \\
\text { painiako prentsaren joera bat izan ohi } \\
\text { da hori (Velte, 2016). } \\
\text { - Langraiz bidea hartutako hiru mili- } \\
\text { tante ageri dira zerrendan: Txelis, } \\
\text { Urrusolo Sistiaga eta Idoia Lopez } \\
\text { Riaño. Bide hori hartu eta Euskal } \\
\text { Preso Politikoen Kolektiboarekin } \\
\text { (EPPK) harremana hautsi duten } \\
\text { presoak } 30 \text { inguru direla kontuan } \\
\text { izanik, eduki hauetan gaindimen- } \\
\text { tsionatuta ageri direla ondoriozta } \\
\text { genezake. } \\
\text { - Oro har, hiru ezaugarri nagusitan ka- } \\
\text { tegoriza ditzakegu ETAren ordezka- } \\
\text { riak, hemen aipatzen diren moduan: } \\
\text { gizonezkoak, erakundeko zuzenda- } \\
\text { riak (eta zuzendari militarrak, bere- } \\
\text { ziki) eta gerora damua agertu dute- } \\
\text { nak. }\end{array}$ \\
\hline
\end{tabular}




\subsubsection{1. «ETAREN INGURUA»-REN IRUDIKAPENA}

Koadernoko 8. orrialdean, ETAren amaiera azaltzeko zerrendatutako faktoreen artean, hainbat sarekadaz mintzo da Herenegun proiektua. «Ustekabeko kolpeak» deitzen die hauei, metafora beliko bat erabiliz eta garaipenezko konnotazioa emanez. ETAko hainbat buruzagiren atxiloketak zerrendatzearekin batera, paragrafo berean topa dezakegu pasarte hau:

1997ko abenduan, «banda armatuarekin lankidetzan aritu izanagatik» Herri Batasuneko 23 buruzagi nagusiak zazpi urteko espetxera kondenatu zituen Auzitegi Gorenak (gerora, zigorrak nabarmen murriztu bazituzten ere); 1998an, Garzón epaileak Egin egunkaria itxi zuen. 1977az geroztik Hernanin zuen egoitza eta ezker abertzalearen espektro ideologikoan eta soziologikoan zegoen kokatua. (8. or.)

Alderdi politikoen ilegalizazioa eta egunkari abertzalearen itxiera ETAren aurkako estrategiaren testuinguruan kokatzen ditu testuak. Oro har konnotazio positibodun atal narratibo baten barruan kokatuta egoteaz gain («ETAren aurkako kolpeak» da paragrafoaren izenburua; dagoeneko eraikita dagoen karratu polarizatzaile batean Gure aldearen interesekin bat datozen elementuak, dira, beraz), pasarte horretako hainbat elementuk gertakarion larritasunaren leuntzaile edo justifikatzaile gisara funtzionatzen dutela beha dezakegu:

- HBko politikariei jarritako zigorrak «gerora nabarmen murriztu» zituzteneko aipamena, parentesi artean; parentesi horrek esaldi horren aurreko zatiarekiko disclaimer edo indargabetzaile moduan funtzionatzen du.

- Egin egunkariaren deskribapena: «ezker abertzalearen espektro ideologikoan eta soziologikoan kokatua» egotea datu naturalizatzailea da kasu honetan, logika bat eskaintzen diolako haren itxierari. Egoitza Hernanin (Gipuzkoa) egoteari buruzko datuak ere funtzio hori betetzen duela ondoriozta dezakegu, ezker abertzalea indartsu egotearen ospea duen udalerri bat izanik, eta hain zuzen ere bi datu horiek bakarrik aipatzen direlako Egin-en izaera edo ibilbide osotik. Informazio baten gehikuntzan oinarritutako justifikazio estrategia bat da; erantsitako elementuari buruzko balioespen moral inplizitua - haren joera politikoa - eransten zaio deskribatutako ekintzari.

Baketze inklusibo eta holistiko baten ikuspegitik - alderdi kulturala eta alde guztien sufrimendua aintzat hartzen dituena - praktika kezkagarria iruditzen zaigu goian aipaturikoa, gatazkaren ondorioetako bat -errepresio politikoa eta adierazpen askatasunaren aurkakoa - sufritu zutenen esperientziarik ez delako ageri; eta, aldiz, gizartearen zati baten aurka hartutako neurri errepresiboak naturalizatzen direlako. 
Bestalde, deigarria da ideia abertzaleak dituen gizarteko sektorea izendatzeko erabiltzen den terminologia. Testuak bi bider aipatzen du «ETAren ingurua» esapidea; behin kakotxez nabarmenduta, adierazpen horiek jatorrian norenak diren aipatu gabe; eta beste behin zuzenean, bere eginez. Erreferentzia interdiskurtsibo baten aurrean gaude, Espainiako Gobernuak eta bertako alderdiek maiz erabili duten formula bat baita «ETAren ingurua»; hain zuzen ere, Euskal Herrian antiterrorismoaren zigilupean sarekada eta atxiloketa handiak agintzeagatik ezagun den Baltasar Garzón epailearen arrazonamenduarekin lotu ohi den esaldi egin bat baitakar gogora —»Dena da ETA»- .

Baketzearen ikuspegitik, arriskutsua da halako adierazpideak galbaherik gabe erreproduzitzea; alde batetik, orokortzaileak direlako eta ez dutelako laguntzen gatazkaren ñabardurak bereizten; aktore baten erretratazio demonizatzailea komunitate politiko oso bati zabaltzen zaio hartara. Bestetik, kasu honetan boterearen diskurtso baten aurrean gaude, boteretik egindako gehiegikeria batzuk - errepresio politikoa, esaterako- justifikatzeko balio izan duena.

\subsubsection{ETAREN BILAKAERA}

Talde armatuaren ibilbideari eta garapen historikoari begiratuta, testuak bi etapa bereizten ditu nabarmen: Trantsiziora artekoa, eta ordutik aurrerakoa. Honelako pasarteetan antzeman daiteke:

«Euskal erakunde independentista horrek indarkeria insurrekzionalari ekin zion 1968an, gero terrorismo eta beste era bateko indarkeria-mota bihurtuko zelarik.» (4.or.)

«1975etik aurrera, ETAren terrorismoa ez da Espainiako zirkunstantzia politikoei emandako erantzuna, ez eta ebatzi gabeko gatazka baten azken ondorioa ere.» (6.or.)

Bi faseen narratiba honek erretratazio demonizatzailea elikatzen du, ulertzera ematen duelako ETAren jardunak bazuela zentzu edo izateko arrazoi bat sorreran, baina ez Trantsiziotik aurrera: haren jardueraren zati handiena ulertezin bihurtzen du hartara, haren arrazoirik bistaratu gabe. Esanguratsuak dira, halaber, bereizketa hori indartzen duten hautu semantikoak: etapa ‘justifikagarriaz' mintzo denean, «euskal erakunde independentista» da ETA; eta bere indarkeria, «insurrekzionala» - konnotazio positiboagoko terminoak biak ere - ; bigarren etapan, ordea, «terrorismoa» da ETArena, termino erabat demonizatzaile bat.

Halaber, bigarren pasarte hori estrategia deuseztatzaile bat ere bada, aurretik gizartearen zati batengan indarrean dagoen, baina hemen esplizitatzen ez den beste diskurtso bati erantzuten diolako: ETAren jarduna bal- 
dintza eta interes-gatazka politiko eta sozial zehatz batzuen ondorioetako bat ere izan zela, besteak beste frankismo osteko Trantsizioaren kudeaketarekin zerikusia zutenak.

ETAren gainbeheraren narratibak hiru fase ditu kontakizun honetan:

a) Jarduera ulergarri edo justifikagarriaren etapa (frankismoan).

b) Balioespen moral batetik, jarduera onartezina bihurtu zen etapa (Trantsizio ostean).

c) Babes soziala galtzea (Miguel Ángel Blancoren hilketatik aurrera, 1997an).

d) Porrot militarra (2000ko urteak).

ETAren amaiera alde bakarreko «gainbehera» gisara deskribatzen da. Ez dira aipatzen talde armatuaren arrazoi posibleak desarmearen bidea aukeratzeko, ez eta gizarte zibilak azken desarmeko ekintzetan izandako protagonismoa ere.

ETAren barnean desarmerako egon zitekeen borondatea behin iradokitzen du testuak:

«2010eko irailaren 5ean, ETAk adierazi zuen defentsarako ekintza armatuak baino ez zituela burutuko; 2011 ko urtarrilaren 10eko beste komunikatu batean, su-eten «iraunkor, orokor eta egiaztagarria» iragarri zuen; eta urriaren 20an, «ekintza armatuak behin betiko bertan behera utzi zituela» deklaratu zuen. (Hori guztia, 53 urte, 853 hildako, eta ETArekin lotutako 3.300 pertsona ingururen atxiloketa eta gero denbora horretan zehar).» (12. or.)

Pasarte honetan ere, aurrekoaren indargabetzaile gisara funtzionatzen du parentesi arteko informazioak: transformazio estrategia bat da, erantsitako arrazionalizazio baten bidez funtzionatzen duena. Kakotxek, gainera, ETAren hitzekiko distantziamendua adierazten dute: narratzaileak ez ditu erabat bere egiten.

Porrot militarra eta ETAren ahulezia hiztegi belikoa erabiliz nabarmentzen dira, garaile posible bakarraren eskema elikatuz: «buruzagitza erori zen», «ETAk ustekabeko kolpe erabakigarriak hartu zituen poliziaren eskutik» eta «kideak errekrutatzeko arazo larriak zituela» bezalako adierazpenekin.

Horrekin batera, gizarteak bere osotasunean ETAri bizkarra eman ziola argudiatzen du testuak, bloke monolitiko bat irudikatuz eta hartara porrot militarra porrot sozial batekin lotuz. ETAren amaiera azaltzen duten kausen artean, bosgarren puntua - azken hirugarrena - da «ezker abertzalearen aurkako presio errepresiboa», eta hura «politikoa, judiziala eta ekonomikoa» izan zela aipatzen da. Orain arte aztertutakoa aintzat hartuta, eta ETAren gainbehera, narratiba honetan, lortu beharreko helburu gisara aurkezten dela onartuta - konnotazio positibo batekin, 
beraz - , errepresio politiko eta judizialaren aipamenak horretarako justifikatzaile gisara funtzionatzen duela ondoriozta genezake; Estatuak indarkeriaz egindako erabilera legitimotzat jotzen dela, beraz, helburu handiago baten mesedetan.

\subsubsection{BESTELAKO ERRETRATAZIOAK}

Aurretik aipatutakoez gain, arreta eman digute ETAri buruz mintzatzeko egindako hautu linguistiko batzuek. Ordezkatze estrategia argi bat identifikatu dugu 8. orrialdeko pasarte honetan:

«(...) "ETAren ingurua" deiturikoek bultzatutako eta gauzatutako mobilizazio eta kale-indarkeriarekin (hau da, kontramanifestazioak, autobusak erre, instalazio eta eraikin esanguratsuak suntsitu, erasoak). Beldurrarazteko modu bat zen, Europako lehen faxisten indarkeria "eskuadrista" gogorarazten zuena eta, zalantzarik gabe, euskal gizartean gero eta indartsuagoa zen bakearen aldeko eta terrorismoaren aurkako mobilizazioa indargabetu nahi zuena eta, aldi berean, kide berriak atxikitzeko baliatu.» (8. or.)

Pasarte honetan, lauki polarizatzaile argi bat zabaltzen da: alde batetik, «euskal gizartea» dago, orokortasunezko adierazpen legitimatzaile batekin deskribatua; haren interesa «bakearen alde» egotea da, beraz, ETAren indarkeriaren aurka. Kontrako aldean, besteenean, ETA eta haren «ingurua» leudeke, interes nagusitzat lehen taldea intimidatzea daukatena, eta horren ondoren, kide berriak lortzea.

Testuak ordezkatze estrategia bat darabil ETA «Europako lehen faxistekin» alderatzen duenean: estrategia horretan, aktore baten ezaugarriak eransten zaizkio besteari. Kasu honetan, faxistekin lotu ohi dira autoritarismoa, gutxiengoekiko mesprezua, botere gehiegikeria, eta hori guztia gauzatzeko indarkeria. Europako faxismoa ideologia eskuindarrekoa zela eta ETAk jatorri marxista-leninista zeukala ez du aipatzen testuak, ezta ETAk sekula ez zuela gobernu-organurik menderatuta eduki ere. Alderaketak informazioaren ikuspegitik datu egokirik argitzen ez duenez, aktore horren erretrataziorako baliabide bat dela ondoriozta dezakegu, beraz.

Unitate didaktiko osoa zeharkatzen duen makronarratiban, kontraesana topatu dugu ETAren babes sozialari dagokionez. Alde batetik, euskal gizarte osoaren interesen aurkako eragile gisara aurkezten da talde armatua, gorago aztertu dugunez; bestalde, ordea, badira tesi hori zalantzan jartzen duten hainbat aipamen. Esate baterako:

«Bere estrategiak gutxietsi ezin den gizarte-babesa izan zuen hauteskundeetan, Gipuzkoan batez ere, eta Nafarroako toki batzuetan (lehen atentatua: J. Imaz Poliziaren komandantea hil zuten 1977ko azaroaren 
26an), non ezker abertzaleak kanpoan utzi zituen EAJ eta EA lehen indar nazionalista gisa. Estrategia horrek - funtsean terrorismoa, indarkeria, beldurraren presioa euskal gizartearengan; noizbehinka herritarren artean gori zegoen gairen bat defendatu, Lemoizko zentral nuklearraren aurkako borroka esaterako - distortsionatu egin zuen demokraziagintza.» (6. or.)

«Erakusgai bat testuinguru honetan: 1981eko otsailean, 8 egunetan, ETAk Jose Maria Ryan Lemoizko Zentral Nuklearraren ingeniaria erail zuen eta Joseba Arregi ETAko kidea hil zen torturen ondorioz. Erantzuna: greba orokor bana eta mobilizazio jendetsuak. Denbora honetan, euskal gizartea harrapatuta, derrigortua, astindua eta isildua, erreferentziarik eta erantzunerako lidergo argirik gabe bizi izan zen.» (26. or.)

Bi pasarte hauetan, hainbat estrategia linguistiko beha ditzakegu:

- Berdintze- edo ordezkatze-estrategia: ETA ezker abertzalearekin parekatzen du, talde armatuaren babes soziala alderdi abertzaleen hauteskundeetako emaitzekin parekatuz.

- Leuntze-estrategia bat: ETAren erretratazio demonizatzaileari jarraikiz, narratiban inkoherentea litzateke aktore horri borondate zintzorik aitortzea. Ondorioz, gizartearen babesa zuten auziak — Lemoiz, adibidez - logika oportunista baten barruan kokatzen dira. Gehikuntza bidezko transformazio-estrategia bat litzateke hau, ebaluazio moral inplizitua duen elementu bat eransten zaiolako deskribatutako ekintzari.

- Orokortze- eta naturalizazio-estrategia transformatzaile bat, autorizazioan oinarrituta dagoena. «Euskal gizarteak» (orokorrean aipatuta, bloke gisara) hartutako jarrera deskribatzen denean, ezinbestekotasunaren narratiba bat eraikitzen du testuak: jendeak behartuta jokatu zuen jokatu zuen moduan, beraz, ez zeukan ardurarik, ezta agentziarik edo erabakitzeko gaitasunik ere. Narratiba hau kokatuta dagoen pasarteko beste adierazpen batekin kontraesanean erortzen da, bi greba orokor egon zirela aipatzen baita. Logikari jarraikiz, nekez irudika litezke grebak isilarazitako gizarte baten ondorio gisara.

- Karga semantiko handiko aditzen eta konnotazio txikiagoko aditzen erabilera. Ryan ingeniaria ETAk «erail zuela» zehazten da testuan: ekintza deskribatzeko (hiltzea), karga indartzailea daukan hiperbole bat erabiltzen da (erailtzea), eta, gainera, ekintzaren subjektua, eragilea, nabarmentzen da (ETAk hil zuen). Aldiz, lerro berean, ETAko kide bat «torturen ondorioz hil zela» azaltzen da, aditz leun edo neutroago bat erabiliz eta tortura horiek eragin zizkion agentea ezkutatuz. Heriotza, hartara, kanpoko kausa baten ondorio natural gisara agertzen da diskurtsoan. 
Funtsean, gatazkaren adierazpena den indarkeriaren ardura alde bakarrean kokatzen du testuak: ETA bihurtzen du haren eragile eta kausa, eta erretratazio demonizatzaile horretatik harago begiratzeko balio lezakeen daturik ez du bistaratzen; are gutxiago baketzearen ikuspegitik gatazkak sortutako eskemak leuntzen lagun dezakeenik. Narratiba honetan, ez da ageri eragile guztien jarduteko arrazoiak ulertzen laguntzen duen daturik; aldiz, haren arabera, ETAren jarduna zentzurik gabeko biolentzia-gose batek eragindakoa da.

\subsubsection{PRESOAK}

Atxiloketak alde batera utzita, apenas topatu dugun presoei buruzko aipamenik. Hiru bider aipatzen dira, honako formula hauekin:

a) «ETAko presoen dispertsio- eta urruntze-politikaren aurka jende asko agertu zen».

b) «Amnistia orokorra. 1977ko abenduan ez da geratzen ETAko preso politikorik Espainiako espetxeetan».

c) «Presoak urrutiagoko espetxeetara bidaltzen hasten dira (dispertsioa)».

Oro har, ETAko kide izateagatik edo harekin harremana izateagatik espetxeratu zituzten pertsonak hartzen ditu aintzat testuak. Halaber, deigarria da «ETAko preso» eta «ETAko preso politikoen» artean egiten duen bereizketa: bigarrenak 1977ko amnistiaren aurretik espetxeratu zituztenak dira. Bereizketa honek gatazkaren bi faseen narratiba elikatzen du, «preso politiko» kontzeptuak legitimitate handiagoa duelako «preso» arruntak baino; lehenari motibazio politiko bat aitortzen zaio, printzipioekin eta idealekin zerikusia duena, ez soilik indarkeriarekin. Trantsizioaren aurretik atxilotutakoak hala izendatuta, jarduera armatuaren 1978 aurreko fasea ulergarriago edo legitimoago agertzen da. 


\subsubsection{Espainiako Gobernuaren irudikapena}

\subsubsection{ESPAINIAKO GOBERNUAREN ETA HARI LOTUTAKO INDARREN IRUDIKAPENA}

4. taula

\section{Espainiako Gobernuaren irudikapena}

\begin{tabular}{|c|c|c|}
\hline & Topatutako adierazpenak & $\begin{array}{c}\text { Inferitutako ideiak / } \\
\text { Behatutako berezitasunak }\end{array}$ \\
\hline \multirow{3}{*}{$\begin{array}{l}\text { Deskribapenak } \\
\text { (adjektiboak, } \\
\text { azalpenak, } \\
\text { etab.) }\end{array}$} & $\begin{array}{l}\text { «Espainiako gobernu demo- } \\
\text { kratiko guztiak» (7. or.) }\end{array}$ & \multirow{3}{*}{$\begin{array}{l}\text { Legitimitatea, batasuna, uniforme- } \\
\text { tasuna. } \\
\text { Helburu legitimoak. } \\
\text { Bakearen alde. } \\
\text { Botere militarra, heroismoa. }\end{array}$} \\
\hline & $\begin{array}{l}\text { «Terrorismoaren aurkako bo- } \\
\text { rroka» (6.-8. or.) }\end{array}$ & \\
\hline & $\begin{array}{l}\text { «Irmotasun handiz erantzun } \\
\text { zien erronka berriei» }(9 . \text { or.) }\end{array}$ & \\
\hline Helburuak & $\begin{array}{l}\text { «ETAk armak uztera era- } \\
\text { mango zuen balizko negozia- } \\
\text { zioa martxan jartzea» }(7 . \text { or.) }\end{array}$ & Bakearen aldeko interesak \\
\hline \multirow[t]{3}{*}{$\begin{array}{l}\text { Egotzitako } \\
\text { ekintzak }\end{array}$} & $\begin{array}{l}\text { «Espainiako Gobernuak, Fe- } \\
\text { lipe Gonzalez sozialista buru } \\
\text { zuela, elkarrizketak hasi zi- } \\
\text { tuen erakundearekin - be- } \\
\text { rehala huts egin zutenak- } \\
\text { ETAk armak uztera eramango } \\
\text { zuen balizko negoziazioa } \\
\text { martxan jartzeko. Espainiako } \\
\text { gobernu demokratiko guztiak } \\
\text { saiatu ziren ETArekin nego- } \\
\text { ziazioak irekitzen, baina de- } \\
\text { nek huts egin zuten. ( } 7 \text {. or.) }\end{array}$ & $\begin{array}{l}\text { Bakerako iniziatiba izatea egozten } \\
\text { zaio, negoziatzeko prest egotea; } \\
\text { bide horren porrota ez zaio berari } \\
\text { egozten («huts egin zuten» esaldi } \\
\text { aseptikoagoa erabiltzen da, subjek- } \\
\text { tua negoziazioak eurak bihurtuz). }\end{array}$ \\
\hline & $\begin{array}{l}\text { «Komando oso garrantzitsuak } \\
\text { atxilotzea lortu zen» }(8 . \text { or.) }\end{array}$ & \multirow[t]{2}{*}{ Botere militarra. } \\
\hline & $\begin{array}{l}\text { «Garai hartako ETAren ku- } \\
\text { pula atxilotzea» (8. or.) }\end{array}$ & \\
\hline $\begin{array}{l}\text { Ordezkariak } \\
\text { (aurpegi } \\
\text { ezagunak eta } \\
\text { izen-abizenekin } \\
\text { aipatuak) }\end{array}$ & $\begin{array}{l}\text { «Felipe Gonzalez» } \\
\text { (7.-16. or.) } \\
\text { «José María Aznar» } \\
\text { (9.-17. or.) }\end{array}$ & $\begin{array}{l}\text { Gobernuburuak, eliteak, gizonez- } \\
\text { koak. }\end{array}$ \\
\hline
\end{tabular}


Oro har, bi taulak aztertuta, honako hau behatu ahal izan dugu:

a) Nabarmena da ETAri buruzko informazio askoz gehiago ageri dela testuan, xehetasun gehiagorekin eta, batez ere, ordezkari zehatz gehiagorekin. Espainiako Gobernuaren kasuan, gatazka armatuan inplikatuta egondako agente gisara, ia ez zaio aurpegi zehatzik jartzen; ondorioz, agentzia hori lausotzen da.

b) Agerian ipinitako aktoreekin jarraituta, kasu honetan ere nabarmena da aipatzen diren ordezkari bakarrak gizonezkoak direla, biak ere elite politikoetakoak.

c) Egotzitako ekintzetan eta deskribapenetarako erabilitako formulazioetan, oro har, adierazpen legitimatzaileak dira nagusi: helburu legitimoak dituztenez (bakea, terrorismoaren aurkako borroka...), indarkeriaz egiten duten erabilera ere legitimatzen da, baita linguistikoki ere: «Terrorismoaren aurkako borroka» formula justifikatzailea da bere horretan, konnotazio demonizatzailea duen elementu bati (terrorismoa) kontrajartzen zaion kontzeptua (borroka) erantzun positibo gisara ulertzen delako.

\subsubsection{ERREPRESIOA}

Oro har, lausotuta ageri dira Espainiako Gobernuari eta hari lotutako indar armatuei egotzi izan zaizkien eskubide urraketak. Horregatik, esanguratsua iruditu zaigu atal berezi batean aztertzea errepresioari unitate didaktikoan ematen zaion trataera.

Errepresioaren aipamen esplizitu bakarrak frankismoko testuinguruan topa ditzakegu, esate baterako, honako hau:

«ETAren ekintzek eta poliziaren errepresioak (errepresio oso bortitza eta indiskriminatua) sortutako espiralak euskal kontzientziak astindu zituen.» (5. or.)

Kasu honetan, errepresioa esplizituki aipatzen den arren, formula naturalizatzaile baten aurrean gaude. Espiralaren metaforak bere burua berez eta bestelako eraginik gabe erreproduzitzen duen indar bat dakar gogora; hartara, «indarkeriak indarkeria sortzen duela» dioen narratiba edo topos-a elikatzen du pasarte honek, gertakarien kausa edo ondorio zehatzik aipatu gabe. Indarkeriaren azalpen naturalizatzaile bat da, haren sorrera eta dimentsioak ulertzen laguntzen ez duena. Halaber, deigarria da errepresioaren aipamenetan ez dela biktimarik edo daturik eskaintzen.

\subsubsection{Biktimak}

Behatu ahal izan dugunez, «biktima» kategoria, oro har, ETAk eragindako biktimak izendatzeko erabiltzen da, eta, zehazki, ETAk hildakoak. 
Azken hauek dira, alde handiarekin, aipamen gehien jasotzen dituztenak testuan zehar. Zenbakitan, datu hauek atera ditugu:
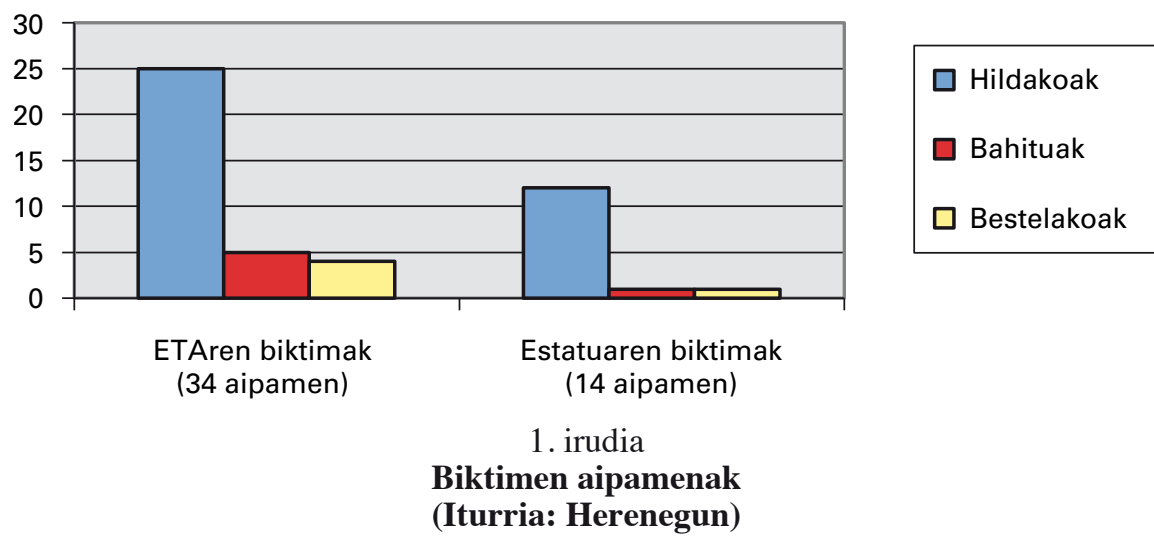

Taulan argi ikus daitekeenez, ETAk eragindako hildakoak dira gehien aipatzen diren biktimak, zenbakitan eta izen-abizenez. Estatuaren biktimak kategorian sartu ditugu GAL eta antzeko talde paramilitarrek eragindakoak ere; 1978 osteko gertakariei dagozkien zazpi aipamenetatik, bost dagozkie GALek eragindako biktimei, hain zuzen ere. Guardia Zibilak eragindakoak eta torturak eragindakoak, bana bakarrik ageri dira.

Horiez gain, frankismoan «exekutatutako» zazpi pertsonaren aipamenak jasotzen dira; horiek ere Estatuaren biktimen kategorian sartu ditugu, eta hark zuzenean edo zeharka eragindako hildakoen kopurutik erdiak baino gehiago dira (1978 ostetik bost hildako, bahitu bat eta desagertu bat).

\subsubsection{ETAREN BIKTIMAK}

Honako adibide hauetan beha dezakegu aipatutako fenomenoa: biktimak izendapen generiko eta neutroa ETAren biktimei buruz aritzeko erabiltzen da, zehaztapenik gabe. Adjektibo edo osagarririk behar ez izateak iruditeria hegemoniko baten parte izatea adierazten du, zehaztapenak nabarmentzen duelako bestetasuna, neutroa ez dena:

«Biktimen elkarteak, biktimak ahaztuta zeudela kontzientzia hartzeko lagundu zutenak.» (7. or.)

«Gertatutakotik larriena izan zen 70eko eta 80ko hamarkadetan biktimak ez zeudela mintzaldi politikoetan, ezta komunikabideetan, ezta Ajuria Eneko Itunaren edukian ere. Ez Euskadi ez Espainian. Zabarkeria eta utzikeria pairatu zuten» (26. or.) 
Bi adibideotan, nabarmena da biktimak formula, berez orokorra dena eta biktima mota guztiak barne hartuko lituzkeena, testuan nagusiki ETAren biktimak kontzeptuaren baliokidetzat jotzen dela. Alde batetik, eurak direlako oro har euren buruari biktimen elkarteak deitzen dieten egituretan antolatuta daudenak, eta, bestetik, gainerakoak adjektiboz edo osagarriz zehaztuta daudelako diskurtsoan, hierarkizazio bat iradokiz: hegemonikoak ez du adjektiborik edo zehaztasunik behar. Areago: bi pasarteotan ebaluazio moral bat eransten da, adierazpenaren esanahia baldintzatzen duena.

Halaber, esanguratsuak iruditu zaizkigu honako pasarte hauek ere:

2011. urtera arte ETAk (haren adar ezberdinek eta kideko taldeek) 853 lagun hil zituzten, 3.000 ekintza terrorista inguru burutu zituen, 82 lagun bahitu eta 10.000 inguru estortsionatu (zerga iraultzailea). Denbora horretan, ETAko eta gertuko taldeetako 150 kide hil ziren segurtasun-indarrekiko enfrentamenduetan, manipulatzen zituzten lehergailuak eztanda eginda, buruaz beste eginda edo argitu ez diren egoeretan, eta 3.300 pertsona inguru espetxeratuak izan ziren. (5. or.)

ETAren lehen erailketa: José Pardines guardia zibila hil zuen kontrol batean Villabonan. Ordu gutxira, ETAko kide Txabi Etxebarrieta hil zen Guardia Zibilarekin izandako tiroketa batean Tolosan. (14. or.)

Bi pasarteotan, hil / erail aditzen eta subjektuen erabileran jarri dugu arreta. Alde batetik, ETAk eragindako biktimen kasuan, subjektua (eragilea) esplizitatzen da, eta aditza, ondorioz, nork-nor formakoa da: egile bat eta biktima bat seinalatzen ditu. Hil zuen aditza erabiltzen da ETAk hildako zibil zein indar armatuei buruz hitz egiterakoan. Aldiz, gatazkaren testuinguruan hildako ETAko kideen kasuan, ez da nork-nor formula erabiltzen, nor baizik. Alegia: hildakoa bakarrik aipatzen da, heriotza eragin duen eragilea esplizitatu gabe.

Hartara, nabarmendutako pasarteetako lehenbizikoan, ETAko kideen heriotzak berez eta logika natural baten barruan gertatu zirela ematen da aditzera, eta hori subjektu agenterik gabeko aditzaren erabilerarekin indartzen da: haiek hil egin ziren. Aldiz, ETAren biktimen kasuan, egiletza nabarmentzen da: ETAk hil egin zituen haiek. Aukeraketa linguistiko honek heriotzak eragiten dituen eragile bakarra ikusarazten du. Ondorioz, kopuruei zein biktimak deskribatzeko erabilitako estrategia linguistikoei erreparatuta, biktimen arteko hierarkizazio bat dagoela ondoriozta daiteke; ez soilik sufrimenduaren eragilearen arabera, baizik eta baita sufritutako kaltearen arabera: gehien ikusarazten diren biktimak hildakoak dira. Lederach eta Galtungen baketze teorien ikuspegitik, ondorio polarizatzaileak dauzkan estrategia linguistiko bat da gatazkaren ondorio biolentoenak eta hildakoak ikusaraztea: kaltearen muturreko adibideak ipintzen dira, konponbide zailena dutenak eta elkarrekiko enpatia gehien zailtzen dutenak. 


\subsubsection{ESTATUAREN ETA INDAR ARMATUEN BIKTIMAK}

Aurretik aipatu dugun moduan, Espainiako Estatuarekin lotutako erakundeetatik, frankismo garaikoak ageri dira, batik bat, indar erreprimitzaile gisara erretratatuta. Garai hartako fusilamenduak eta bestelako «exekuzioetarako» erabilitako metodoak xehetasunez deskribatzen dira testuan, bi faseen narratiba elikatuz: gatazka politiko eta armatua frankismo garaiaren ondorio gisara deskribatzen du. Unitate didaktikoko lehenbiziko koadernoko 6. orrialdean ageri den pasarte honek laburtzen du unitateak errepresioari buruz ematen duen informazioaren zati handiena:

«1976 eta 2001 bitartean, ETAren adar ezberdinetako 114 kide inguru hil ziren Poliziarekin izandako enfrentamenduetan (edo ETAko kideek eurek izandako istripuetan). Polizia-lanaren ezintasunaren aurrean, terrorismoaren aurkako borrokaren arduradunek «gerra zikina»ren metodoak erabili zituzten: talde paramilitarrak antolatu zituzten, tortura erabili eta giza eskubideen beste urraketa batzuk egin zituzten. Triple A, GAL, Batallón Vasco Español eta antzeko taldeek 46 lagun hil zituzten, eta horien artean,1977ko abenduan, Argala, ETAko buruzagietako bat eta Carrero Blancoren aurkako atentatuaren erantzulea. GALek (Grupos Antiterroristas de Liberación), bestalde, 29 pertsona hil zituen: ETAko 16 errefuxiatu eta 13 zibil (HBko Santiago Brouard eta Josu Muguruza, besteak beste). Gertakari horietan parte hartzeagatik kondenatu zituzten Amedo eta Dominguez poliziak, Guardia Zibilaren jeneral Enrique R. Galindo, Rafael Vera, Segurtasuneko Estatuko idazkari ohia, Bizkaiko gobernadore zibila Julian Sancristobal, eta haien laguntzaileak.» (6. or.)

Pasarte honetan, hainbat elementu nabarmendu ditzakegu:

a) Enfrentamenduaren ideia: ETAko kideak «Poliziarekin enfrentamenduetan hil zirela» aipatzeak, ez du soilik, lehen aztertu dugun moduan, hilketa horien egiletza lausotzen (Polizia); enfrentamenduaren irudiak pareko baldintzetan ebazten den bataila baten testuingurua eraikitzen du; eta, ondorioz, emaitza (heriotza) gerra-logika horren ondorio naturaltzat agertzen da.

b) «Gerra zikina», talde paramilitarren sorrera eta haien erabilera, ezintasun baten ondorio gisara aurkezten da. Saihestezintasunaren narratiba justifikatzaile bat eraikitzen da hartara: Estatuak ez zuen halakorik egin nahi, baina ez zuen beste modurik topatu. Funtsean, gatazka ebazteko eskema militarra elikatzen jarraitzen du egitura honek, bakea norberaren aldearen segurtasun gisara ulertuta (bake negatiboa), eta egoera despolarizatu bat irudikatu gabe.

c) Kondenen aipamena: Paragrafo honetan aipatzen diren pertsonaien aurkezpenari erreparatzea ere interesgarria da bakoitzari eransten zaizkion konnotazioak aztertzeko. Argalaren hilketaz ari de- 
nean, hari leporatzen zitzaion atentatu baten informazioa eransten zaio (zeinetan protagonista errudun eta indarkeriaren erantzule gisara erretratatzen baita); aldiz, GALengatik auzipetutako pertsonen kasuan, justiziak zigortu egin zituela da eransten den informazioa. Azken honetan elipsi nabarmen bat topa dezakegu; izan ere, ez da aipatzen gero kondenatu gehienek ez zutela zigorra osorik bete. Hartara, eskaintzen den informazio osagarri bakarrak justiziaren jarduna legitimatzen du, auzia ebatzia izan zela ulertaraziz. Hain zuzen ere, auzi horri buruzko aipamen bakarra topatu dugu, 7. orrialdean: "prozesu judizialek, espetxeratzeek eta indultuek zeresan eta erreakzio ugari ekarri» zituztela aipatzen da bertan. Termino neutralen aukeraketa bat antzeman dezakegu («zeresan eta erreakzio ugari»), gaitzespena nabarmendu ordez balorazioa apaltzen dutenak. Giza eskubideen urraketa larriekin zerikusia daukan gatazkaren alde bat leuntzen da hartara.

\subsubsection{TALDE PARAMILITARREN BIKTIMAK}

Zuzenean Estatuaren menpe dauden indarrek (Guardia Zibilak, Espainiako Poliziak) eragindako biktimek baino arreta dezente handiagoa jasotzen dute GAL, BVE, Triple A eta antzeko talde paramilitarrek eragindakoek. Hauek guztiak «gerra zikina» metaforarekin taldekatzen ditu unitate didaktikoak; metaforak berak inplikatzen du beste gerra «garbiago» bat, legitimoagoa - poliziala - existitzen zela. Auzi honi dagokionez, hiru pasarte nagusi nabarmenduko ditugu:

«Gerra zikina» erantzuna emateko terrorismoa izan zen. (...) Estatuko estamentuekin lotutako sektoreak ados zeuden; jakinaren gainean egon ziren edota konplizeak ere izan ziren kasu batzuetan. Bere jatorria eta izaera kontuan hartuta, Espainiako estatuaren zilegitasuna bera kolokan jarri zuen. (...) Triple A edo BVEren atentatuek, eta bereziki GALen hilketek (1987ra arte luzatu ziren) utzitako arrastoak nolabaiteko aurrez aurreko indarkeriaren pertzepzioa izatea eragin zuen. Horrez gain, belaunaldi-errelebo negargarria eragin zuen ulermenean, babesean edo militantzian ETAtik gertuen zeuden sektore soziopolitikoetan. (7. or.)

Hiru pasarteek egitura justifikatzaile bat dute oinarrian (lehenbiziko aipua): talde paramilitarrak, funtsean, ETAk eragindako indarkeriaren ondorio bat ziren. Ondorio saihestezinaren narratiba elikatzen da hartara; fenomenoa naturalizatzen duena. Galtungen printzipioetara itzuliz, narratiba honek fokoa gatazkaren eszenatokian ipintzen duela ondoriozta dezakegu; lehen harria nork bota ote zuen galderari bilatzen dizkiola erantzunak (kasu honetan, ardura ETAri egozten dio, eta paramilitarismoa haren ondorio saihestezin gisara aurkezten da). 
Bestalde, talde paramilitarren jarduna Estatuarekin lotzen da zuzenean, nahiz eta erantzule gisara haren barruko alderdi batzuk aipatzen diren. Narratiba honen arabera, paramilitarismoaren ondorio kaltegarriena izan zen ETAren aurkako eragileek sinesgarritasuna galtzea, eta ETA gazte berrien artean indartzea. Irakurketa hau gerra-narratiben ikuspegitik eginda dago, berriz erreproduzitzen baitu arestian aipatutako karratu polarizatzailea ( $g u$ haiek egitura dikotomikoa): norbere bandoaren interesen arabera ebaluatzen da negatibotzat paramilitarismoa. Baketzearen aldeko irakurketa batek, aldiz, beste ikuspegi batetik egingo luke ebaluazioa, urratutako giza eskubideen ikuspegitik, hain zuzen ere: ondorio negatiboa, kasu horretan, gizartearen zati baten eskubideak larriki urratu zirela izango litzateke, baita eragileak norbere interesak partekatuko balitu ere.

\subsubsection{TORTURAREN BIKTIMAK}

Torturaren zazpi aipamen topatu ditugu testuan. Horietatik bost orokorrak dira (tortura bere horretan aipatzen da, zehaztasunik edo adibiderik erantsi gabe); eta beste bietan torturaren hiru biktima aipatzen dira: Joseba Arregi, Joxean Lasa eta Joxi Zabala. Lehenbiziko DGSren (Segurtasunerako Zuzendaritza Orokorraren) torturapean hil zuten; frankismo garaiko erakunde polizial batean, alegia (trantsizioan izan arren). Beste biak GALek torturatu eta hil zituen. Unitate didaktikoan ez da ageri Guardia Zibilari eta bestelako polizia erakunde garaikideei egotzitako tortura salaketen aipamen espliziturik, ezta Eusko Jaurlaritzaren beraren txostenetan egiaztatutako 4.000 kasu baino gehiagoren berririk ere. Amaierako eranskinetako oharretako batean soilik topa daiteke honako aipamen hau: «Tortura eta tratu txarren milaka salaketa zenbatu ziren. Nazioarteko erakundeen arabera, tortura ez zen izan sistematikoa ezta soilik noizbehinkakoa ere». Ukazio bikoitzaren bidez definitzen da kasu honetan tortura; ez-definizio baten aurrean gaude, beraz, gaiari iskin egiten diona. Galdera berez sortzen baita: tortura ez bazen sistematikoa izan, baina ezta noizbehinkakoa ere, zer izan zen?

\subsubsection{SAKABANAKETAREN BIKTIMAK}

Ez dugu biktima mota honi buruzko aipamenik topatu. Sakabanaketa politikaren aurkako erresistentzia soziala aipatzen da, baina ez da agertzen haren ondorioz kaltea sufritu dutenen kasu edo adibiderik. 


\subsection{Bake iniziatibak}

5.3.1. Esplizituki bakeari lotuta aipatzen diren eragile eta aktore zehatzak

5. taula

Bakeari lotutako aktoreak

\begin{tabular}{c|l}
\hline Aipatutako aktorea & \multicolumn{1}{c}{ Deskribapena edo zehaztapenak } \\
\hline $\begin{array}{c}\text { Denon Artean, Gesto } \\
\text { por la Paz, Bakea } \\
\text { Orain, Elkarri }\end{array}$ & «Erakunde bakezaleak» \\
\hline ETAko preso batzuk & $\begin{array}{l}\text { lis, Kepa Pikabea, Carmen Gisasola, Joseba Urrusolo, } \\
\text { esaterako) indarkeriaren aurkako jarrera ezagutzera eman } \\
\text { zuten» }\end{array}$ \\
\hline Foro Soziala & $\begin{array}{l}\text { «Ezker abertzaleak eta gizarte-talde ezberdinak biltzen zi- } \\
\text { tuen» }\end{array}$ \\
\hline Bakearen Artisauak & «Elkarretaratzea isilik, indarkeriaren aurka» \\
\hline $\begin{array}{c}\text { Bakegintza eta } \\
\text { Bizikidetzarako }\end{array}$ & Ez du deskribapen edo datu gehigarririk eskaintzen. \\
Idazkaritza Nagusia & \\
\hline
\end{tabular}

\subsubsection{Bake terminoaren erabilera}

Aurreko taulan beha daitekeenez, indarkeria fisikorik erabiltzen ez duten edo haren aurkako jarrera adierazten duten eragileak definitzen dira bakearen aldeko eragile moduan. Areago: ETAren azken hamarkadotako jardun armatua gaitzesten dutenak ere barne biltzen ditu kategorizazioak. Horren adibide da unitate didaktikoak ETAko preso batzuek «bakearen alde» egindako urratsak nabarmentzen dituela, hain zuzen ere, erakundetik apartatu direnean (Langraitz bidea hartu dutenen kasua da, EPPK Euskal Preso Politikoen Kolektiboarekin harremanik ez dutenak).

Deigarria iruditu zaizkigu, halaber, ekintzaile edo talde desberdinak definitzeko erabilitako baliabideak: Denon Artean, Bakearen Aldeko Koordinakundea-Gesto por la Paz, Bakea Orain eta Elkarri, publikoki batez ere ETAren aurka agertu ziren taldeak, «erakunde bakezale» gisara definitzen dira, bestelako xehetasunik erantsi gabe; biktimen atealean ikusi moduan, arlo honetako eragile neutro eta hegemoniko gisara agertzen dira, eta zehaztapen faltak nabarmentzen du neutraltasun hori. Ostera, Bakearen Artisauez, hain zuzen ere ETAren desarmean inplikatutako eta horretarako erakundearekin harreman zuzena izan zuen herritar taldeaz, ez da era 
horretako definiziorik eskaintzen, ez eta ETAren desarmean izan zuten rolari buruzko daturik ematen ere; soilik «elkarretaratze isila» egin zutela aipatzen da. Halaber, gatazkaren ondorioei buruzko lanketa zabala egin duen Foro Sozialaren kasuan, haren joera politikoa nabarmentzea erabaki dute material didaktikoaren egileek, ezker abertzaletik gertu dagoela nabarmenduz. Aukeraketa linguistiko horiek lehenbizi aiptutako taldeen aldeko joera adierazten dute, eragile unibertsal, desideologizatu eta neutral gisara agertzen direlako erretratatuta.

\subsubsection{Negoziazio prozesuak}

Orain arte ikusi dugun moduan, testuaren narratiba nagusiek bake negatibo baten ideia elikatzen dute, nagusiki norberaren segurtasunean oinarritzen dena eta horretarako bestearen porrot militar eta soziala (suntsipena) eskatzen dituena, baina ez duena harreman despolarizaturik edo irtenbide sortzaile partekaturik aintzat hartzen. Nolanahi ere, testuak eskaintzen die arreta gatazkaren historiako hainbat negoziazio prozesuri, nahiz eta, ikusiko dugun moduan, horien inguruko narratibek ere ez duten bake positibo baten eskema elikatzen. Batez ere 1990eko hamarkadaren bigarren erditik honako negoziazio prozesuak jorratzen ditu testuak. Horien artean nabarmenena Lizarra-Garaziko prozesua (1998) da.

«Hona itun horrek proposatzen zuena: elkarrizketa eta negoziazio prozesu irekia eta inor kanpoan utzi gabe, «inolako indarkeria adierazpenik gabeko» baldintzapean eta gatazkaren arrazoitzat jotzen ziren gaiak («lurraldetasuna», «erabakiaren subjektua» eta «subiranotasun politikoa») aztertu eta irtenbide bat ematea ahalbidetuko zuena. (...) Lizarra-Garaziko Itunera batutako erakunde sozial, politiko eta sindikal ia guztiak nazionalistak ziren, eta ezker abertzalea politika autonomikoan eta instituzionalean integratzeko eta bakegintzarako benetako aukeraren funts politiko gisa aurkeztu zuten ituna. Aukera horrek ez zuen, ordea, behar beste integratzen euskal politikaren pluraltasuna. Lizarra-Garaziko Itunak herriaren zatiketa sakondu baino ez zuen egin. (9.or.)

Lehenbiziko pasartean, nabarmena da bertan ageri diren edukiekiko distantziamendua: kakotxak erabiliz, negoziazio prozesuan sartuta zeudenen helburuetatik distantzia hartzen du narratzaileak. Bigarren pasartea nabarmen baloratiboa da, arestian aipatutako «nazionalista / ez-nazionalista» dikotomiaz gain - oro har, espainiar nazionalismo baten ikuspegitik egiten den banaketa, soilik alderdi abertzaleei egozten zaielako nazionalismoa, norberaren eredu neutral eta hegemonikoa esplizitatu gabe utziz-, Lizarra-Garaziko prozesuari ondorio negatibo bat soilik egozten zaiolako: zatiketa areagotzea. Narratiba honek talka egiten du prozesu hartaz gizartearen zati batengan existitzen den beste diskurtso batekin: hain zuzen ere, batasunezko garai bat zela, alderdi abertzaleen adostasuna posible zela ikusi 
zutelako askok. Horixe da, hain zuzen ere, unitate didaktikoak negatibotzat jotzen duen elementua; ondoriozta daiteke, beraz, alderdi ez-abertzaleekin identifikatzen diren aktoreen ikuspegitik egindako balorazio bat dela nagusi. Aukera politiko bat - abertzaleen arteko akordioa, burujabetzaren aldekoa - deslegitimatzen da.

\section{ONDORIOAK ETA PROPOSAMENAK}

Galtungek zehaztutako bakea ulertzeko bi moduen artean, Herenegun unitate didaktikoak bake negatiboa deritzona elikatzen duela behatu ahal izan dugu. Eredu honek gatazkaren barruan eraikitako eskema polarizatuei eusten die, bi alde bereiziz: batean leudeke ETA eta abertzaletasuna, eta, bestean, euskal gizartea (orokortasunez erretratatua), herritar ez-abertzaleak, ETAren aurkako eragileak (tartean Estatua eta Polizia erakundeak) eta biktimak. Unitatearen hainbat ataletan identifikatu ditugu lehenbiziko taldea (Besteak / outgroup) demonizatzen edo deslegitimatzen duten estrategia linguistikoak, eta, kontrara, norberaren aldea legitimatzen duten deskribapen eta aurkezpen positiboak. Testuak hartzen duen posizio argiari jarraikiz, leundu egiten dira norberaren aldearen eskubide urraketak: tortura, esate baterako.

Eskema horretan, bakea soilik alde baten interesen arabera eraikitzen da: norberaren segurtasuna bermatzen duten iniziatibak jotzen dira bake iniziatibatzat - bide militarra, beste aldearen porrot fisiko zein soziala ahalbidetzen duten estrategiak - . Bakea biolentzia ezaren moduan ulertzen da, baina, batez ere, aktore baten desagerpenarekin parekatzen da (ETAren desagerpenarekin). Ondorioz, Galtungek deskribatutako zero-sum orientation edo garaile bakarreko ikuspegia elikatzen dute identifikatutako narratibek: bakerako ezinbesteko baldintza bestearen deuseztapena da. $\mathrm{Ne}$ goziazio prozesuak ere testuinguru horretan baloratzen dira: norberaren interesentzako izan duten garrantziaren arabera.

Ikusarazten diren aktore eta gertakariei dagokienez, narrazioak fokua gatazkaren jokalekuan ipintzen du, haren ondorio ikusgarri eta biolentoenei arreta handiena eskainiz: hildakoei, hain zuzen ere. Hartara, gatazkaren biktimen hierarkizazio bat antzematen da, ez soilik sufrimenduaren eragilearen araberakoa (ETAren biktimek arreta handiagoa jasotzen dute Estatuaren biktimek baino), baizik eta baita sufrimendu motaren arabera. Gatazkaren irudikapen polarizatua elikatzen da hartara: ez dira aintzat hartzen gatazkaren adierazpen biolento eta ofizialetik haragoko esperientziak, kolektibo gutxituenak eta euren bizipenak entzunarazteko baliabide gutxien dituztenenak (emakumeak, presoak, erbesteratuak, etab.). Horren ordez, nagusiki gatazkaren alderdi militar eta biolentoan inplikatutako pertsonaiak ageri dira irudikatuta, gehienak gizonezkoak eta era batera edo bestera eliteetakoak (alde desberdinetako agintari politiko eta militarrak). 
Finean, unitate didaktiko honetan eraikitzen den karratu ideologikoak ez du laguntzen gatazkan inplikatutako motibazio eta interes politiko ezberdinak ulertzen, eta ez du tarterik uzten narratiba-aniztasunerako. Aitzitik, eraikitzen duen zuri-beltzeko kontakizunak tabuaren esparrua handitzen du, esan ezin dena demonizazioa sufritzeko arriskuan utziz. Narratiba ofizialarekin bat etor ez daitezkeen ahotsak entzunaraztea eragozten duen material didaktiko baten aurrean gaude, beraz; finean, ikasgelan eztabaida eta narratiba aniztasuna sustatu ordez, hura eragozten duena.

Kontrara, gatazkaren esperientzia ez hain polarizatuak ikusarazten dituzten material didaktikoak diseinatzea proposatzen dugu, Galtungen baketze holistikoaren teoriari jarraikiz, gatazkaren garaian eraikitako konfrontaziozko eskemak leuntzen lagunduko dutenak, baina, batez ere, narratiba-aniztasunean oinarrituta daudenak, aniztasun horrek eskainiko baitie iragan eta jatorri ugaritako belaunaldi berriei elkar topatzeko espazioa, eta hain ikusgarriak ez diren gatazkaren ondorio sozialak esploratzeko tokia. Areago: aztertutako material didaktikoak, eduki historiografiko moduan aurkezten den arren, bokazio moralizatzailea duela suma daiteke; gatazkaren irakurketa jakin bat bultzatu, eta, zehazki, ETAren indarkeriaren erabilera gaitzesteko diseinatuta dagoen hezibidea da. Horren aurrean, hezkuntza arautu zein ez arautuko eragileek hausnartzeko galderetako bat da ea zein funtzio aitortzen diegun mota honetako edukiei: ikuspegi historiografiko batetik landu nahi ote diren, edota ikuspegi etiko edo filosofiko batetik, horren arabera asko alda baitaiteke edukioi ikasgelan emango zaien trataera.

\section{ERREFERENTZIAK}

Cabezudo, A., \& Haavelsrud, M. (2007). Rethinking peace education. In Webel, C. eta Galtung, J. (Zuz.) Handbook of Peace and Conflict Studies. Oxon: Routledge.

Calsamiglia, H., \& Tusón, A. (2012). Las cosas del decir. Manual de análisis del discurso. Bartzelona: Editorial Planeta.

Devine, P., \& Schubotz, D. (2010). «Caught up in the past»? The views of 16-year olds on community relations in Northern Ireland. Shared Space, 10, 5-22.

Euskadiko Gazteriaren Kontseilua (EGK). (2018). Gazteon aukera, elkarbizitzaren erronka [Dokumentala]. Retrieved from https://www.youtube.com/ watch?v=Vn47To_SqsM

Fivush, R. (2010). Speaking silence: The social construction of silence in autobiographical and cultural narratives. Memory, 18(2), 88-98.

Galtung, J. (1996). Peace by peaceful means. Peace and Conflict, Development and Civilization. London: Sage.

Galtung, J. (2003). Violencia cultural. Gernika Gogoratuz, 14.

Galtung, J., \& Fischer, Dietrich. (2013). Johan Galtung. Pioneer of Peace Research. Heidelberg: Springer. 
Goikoetxea, G. (2019/01/24). Liskar politikoen eraginez eten dute eskoletan indarkeria lantzeko plana. Berria, 2-3.

Idoiaga, P., \& Ramírez de la Piscina. (2002). Al filo de la (in)comunicación: prensa y conflicto vasco. Madril: Fundamentos.

Kress, G. (2011). Discourse Analysis and Education: A Multimodal Social Semiotic Approach. In Rogers, R. (Zuz.) An Introduction to Critical Discourse Analysis in Education. New York: Routledge.

Lederach, J. P. (1998). Construyendo la paz: Reconciliación sostenible en sociedades divididas. Gernika-Lumo/Bilbao: Bakeaz / Gernika Gogoratuz.

Murua Uria, I. (2015). The End of ETA: errelatuaren borroka akademian. Jakin, 209, 101-116.

Reidy, C. M., Taylor, L. K., Merrilees, C. E., Ajdukovic, D., Corkalo Biruski, D., \& Cummings, E. M. (2015). The political socialization of youth in a post-conflict community. International Journal of Intercultural Relations, 45, 11-23.

Van Dijk, T. A. (2003). The Discourse-Knowledge Interface. In Weiss, G. and Wodak, R. (2002), Critical Discourse Analysis. Theory and Interdisciplinarity. New York: Palgrave Macmillan.

Van Dijk, T. A. (1990). La noticia como discurso. Comprensión, estructura y producción de la información. Barcelona: Paidos.

Van Leuwen, T., \& Wodak, R. (1999). Legitimizing immigration control: a discourse-historical analysis. Discourse Studies, 1(1), 83-117.

Velte, S. (2016). La representación de los presos políticos vascos en la prensa española (2011-2016). Discurso \& Sociedad, 10(3), 491-544.

Velte, S. (2018). Oñati's Youth Facing the Armed Conflict: Analysing the Discourses of the First Post-Conflict Generation. Oñati Socio-Legal Series, Forthcoming. Available from: http://ssrn.com/abstract=3284366

Webel, C., \& Galtung, J. (2007). Handbook of Peace and Conflict Studies. Oxon: Routledge. 